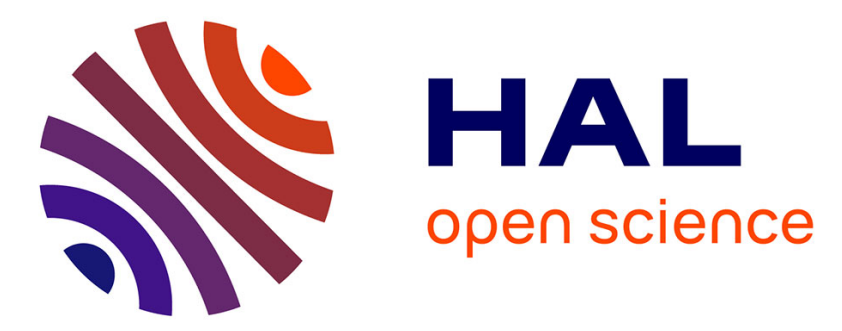

\title{
Long-term response of an arctic fiord system to lead-zinc mining and submarine disposal of mine waste (Maarmorilik, West Greenland)
}

\author{
Jens Søndergaard, Gert Asmund, Poul Johansen, Frank Rigét
}

\section{To cite this version:}

Jens Søndergaard, Gert Asmund, Poul Johansen, Frank Rigét. Long-term response of an arctic fiord system to lead-zinc mining and submarine disposal of mine waste (Maarmorilik, West Greenland). Marine Environmental Research, 2011, 10.1016/j.marenvres.2011.03.001 . hal-00703488

\section{HAL Id: hal-00703488 \\ https://hal.science/hal-00703488}

Submitted on 2 Jun 2012

HAL is a multi-disciplinary open access archive for the deposit and dissemination of scientific research documents, whether they are published or not. The documents may come from teaching and research institutions in France or abroad, or from public or private research centers.
L'archive ouverte pluridisciplinaire HAL, est destinée au dépôt et à la diffusion de documents scientifiques de niveau recherche, publiés ou non, émanant des établissements d'enseignement et de recherche français ou étrangers, des laboratoires publics ou privés. 


\section{Accepted Manuscript}

Title: Long-term response of an arctic fiord system to lead-zinc mining and submarine disposal of mine waste (Maarmorilik, West Greenland)

Authors: Jens Søndergaard, Gert Asmund, Poul Johansen, Frank Rigét

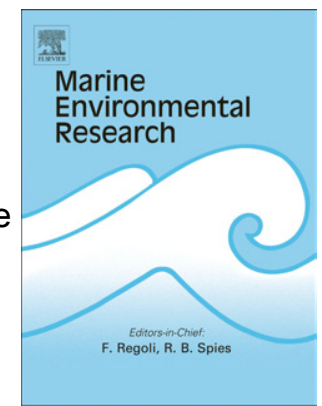

PII:

S0141-1136(11)00042-0

DOI:

10.1016/j.marenvres.2011.03.001

Reference: MERE 3515

To appear in: Marine Environmental Research

Received Date: 10 November 2010

Revised Date: 15 March 2011

Accepted Date: 16 March 2011

Please cite this article as: Søndergaard, J., Asmund, G., Johansen, P., Rigét, F. Long-term response of an arctic fiord system to lead-zinc mining and submarine disposal of mine waste (Maarmorilik, West Greenland), Marine Environmental Research (2011), doi: 10.1016/j.marenvres.2011.03.001

This is a PDF file of an unedited manuscript that has been accepted for publication. As a service to our customers we are providing this early version of the manuscript. The manuscript will undergo copyediting, typesetting, and review of the resulting proof before it is published in its final form. Please note that during the production process errors may be discovered which could affect the content, and all legal disclaimers that apply to the journal pertain. 


\title{
Long-term response of an arctic fiord system to lead-zinc mining and
}

\section{submarine disposal of mine waste (Maarmorilik, West Greenland).}

\author{
Jens Søndergaard ${ }^{\mathrm{a}, *}$, Gert Asmund $^{\mathrm{a}}$, Poul Johansen ${ }^{\mathrm{a}}$, Frank Rigét $^{\mathrm{a}}$
}

a Department of Arctic Environment, National Environmental Research Institute, Aarhus University, Frederiksborgvej 399, DK-4000 Roskilde, Denmark

*corresponding author:

Department of Arctic Environment, National Environmental Research Institute, University of Aarhus, Frederiksborgvej 399, DK-4000 Roskilde, Denmark

Phone: +45 46301966

E-mail: jens@dmu.dk

Prepared for Marine Environmental Research, 2010 


\begin{abstract}
Contamination by lead $(\mathrm{Pb})$ and zinc $(\mathrm{Zn})$ was studied in seawater, sediment, seaweed and blue mussels near the former "Black Angel Pb-Zn Mine" in Maarmorilik, West Greenland. The mine was operated during the period 1973-90 when mine waste (tailings and later waste rock) was discharged directly into the sea. Metal concentrations peaked during the mining period and $\mathrm{Pb}$ and $\mathrm{Zn}$ in seawater within the discharge area were measured up to 440 and $791 \mu \mathrm{g} \mathrm{L}^{-1}$, respectively. $\mathrm{Pb}$ concentrations in sediment, seaweed and mussels just outside the discharge area were measured up to 187,84 and 2,650 and $\mathrm{Zn}$ up to 655,363 and 1,190 $\mu \mathrm{g} \mathrm{g}^{-1}$ dry wt., respectively. Within the discharge area, seawater metal concentrations (especially $\mathrm{Pb}$ ) decreased abruptly after mine closure. Metals concentrations in sediment and biota, however, decrease more slowly and two decades after mine closure seaweed and blue mussels are still contaminated $12 \mathrm{~km}$ from the mine.
\end{abstract}

\title{
Keywords
}

Mining; Submarine tailings disposal; Pollution monitoring; Heavy metals; Lead; Zinc; Mytilus edulis; Fucus vesiculosus; Greenland; Arctic

\section{Introduction}

The Black Angel Lead-Zinc Mine in Maarmorilik in West Greenland (Figure 1) is an important example in mining history where discharge of waste materials into the sea caused a significant release and dispersion of metals within a larger fiord system (Asmund, 1992a; Larsen et al., 2001; Elberling et al., 2002). The Black Angel Mine was operated between 1973 and 1990 and during this period, so-called mine tailings from ore treatment were discharged into a small partly-enclosed fiord Affarlikassaa (named the A-fiord). In the years after the tailings disposal began, elevated concentrations of metals including lead $(\mathrm{Pb})$ and zinc $(\mathrm{Zn})$ were found in seawater, sediment and biota, not only in the A-fiord but also in a larger area covering the outer fiord Qaamarujuk (Qfiord). Later, detailed geochemical studies revealed that the tailings contained significant amounts of $\mathrm{Pb}$ and $\mathrm{Zn}$ minerals that were soluble in the ambient seawater (Poling and Ellis, 1995). Furthermore, seasonal destratification of the water body in the A-fiord was found to take place during winter/spring, which allowed for a complete mixing of surface water with metal-rich bottom water and subsequently a dispersal of contaminants over the sill between the A-fiord and the Qfiord (Poling and Ellis, 1995). Other sources of contamination in Maarmorilik include dust from the ore-milling process and dumps of waste rock established on land below the mine entrances containing rocks with elevated levels of $\mathrm{Pb}$ and $\mathrm{Zn}$. The largest and most contaminating of the land- 
based waste rock dumps was removed to the extent possible and the waste rock disposed on top of the tailings in the A-fiord as part of the mine closure plan in 1990.

Today (2010), there are ongoing plans to re-open the mine within the next few years and this study seeks to evaluate the present state of the environment in the A- and Q-fiords 20 years after mineclosure. This is important not only as an environmental "baseline study" for the re-opening of the mine but also as a study of long-term recovery of an arctic fiord system subjected to mining pollution, which may also provide a valuable reference for future cases of submarine tailings disposal. The study is based on analyses of seawater, sediment and the marine organisms - seaweed (Fucus vesiculosus/Fucus distichus) and blue mussels (Mytilus edulis). These relatively sedentary organisms concentrate metals, reflect different bioavailable metal-sources within the seawater and have been used as biological monitors of heavy metal pollution in a number of previous studies, including the so-called Mussel Watch Programs (Rainbow, 1995; Cairrao et al., 2007; O'Connor and Lauenstein, 2006; Torres et al., 2008). Data include those from samples taken during the mining period before 1990 and until 2009 and make a detailed consistent record of high-resolution data from environmental monitoring and research in the area.

\section{Site description}

Maarmorilik is situated adjacent to the two fiords, Affarlikassaa and Qaamarujuk (A- and Q-fiords), in the inner part of the Uummannaq fiord complex in West Greenland $\left(71^{\circ} 07^{\prime} \mathrm{N} ; 51^{\circ} 15^{\prime} \mathrm{W}\right)$ (Figure 1). The closest community is Ukkussissat, $25 \mathrm{~km}$ to the west and Uummannaq, the main settlement in the area, is situated $80 \mathrm{~km}$ south of Maarmorilik. The climate is arctic with maximum summer temperatures around $10^{\circ} \mathrm{C}$ and minimum winter temperatures below $-30^{\circ} \mathrm{C}$. Winds are dominated by strong easterly winds coming from the Greenland Ice Sheet in the bottom of the Qfiord, which result in sparse precipitation in the area $(<100 \mathrm{~mm}$ a year).

The A-fiord covers an area of $2 \mathrm{~km}^{2}$ and has an average water depth of $30 \mathrm{~m}$. The fiord is partly separated from the outer Q-fiord by a sill at $23 \mathrm{~m}$ depth. The A- and Q-fiords can be described as stratified estuaries during summer. The stratification is caused by melt water from the rivers that flow on top of the heavier seawater creating a distinct and roughly stagnant water mass in the bottom of the Q-fiord and A-fiord. The annual fresh water input to the Q-fiord equals approximately $90 \times 10^{6} \mathrm{~m}^{3}$ from the river in the bottom of the A-fiord and $22 \times 10^{6} \mathrm{~m}^{3}$ from the Wegener River in the inner part of the Q-fiord (Møller, 1984). In almost every winter, however, a complete vertical mixing of the stratified water bodies take place due to freezing of the surface water and water inflow over the sill between the A-fiord and Q-fiord (Møller, 1984). The annual seawater 
temperatures in the fiords range between -2 and $5^{\circ} \mathrm{C}$, the salinity between 31 and $34 \mathrm{psu}$ and the $\mathrm{pH}$ between 7.8 and 8.1. The tidal range in the fiords is around $1 \mathrm{~m}$ and sea ice, $0.5-1 \mathrm{~m}$ thick, usually develops in October and covers the fiords until May.

The geological Maarmorilik Formation includes many carbonate-hosted $\mathrm{Pb}-\mathrm{Zn}$ ores, which are primarily located in the 'Black Angel Mountain', and the area is part of the Archean Foxe-Rinkian mobile belt complex of North-East Canada and Central West Greenland (Escher and Pulvartaft, 1976). The name "Black Angel" refers to a pelite outcrop forming a dark angel-like figure high on a $1100 \mathrm{~m}$ marble cliff face above the A-fiord. The massive ores, up to $30 \mathrm{~m}$ thick, consist of galena $(\mathrm{PbS})$, sphalerite $(\mathrm{ZnS})$ and pyrite $\left(\mathrm{FeS}_{2}\right)$ with accessory ore minerals such as pyrrhotite, chalcopyrite, tennantite and arsenopyrite. Prior to mining, the Black Angel deposit consisted of ten major ore bodies with a total of $13.6 \times 10^{6}$ tons containing $4.0 \% \mathrm{~Pb}, 12.3 \% \mathrm{Zn}$ and $29 \mathrm{ppm} \mathrm{Ag}$. Out of these, $11.2 \times 10^{6}$ tons were mined in the period $1973-90$ by the company Greenex A/S (Thomassen, 2003).

During the mining process, ore material was transported from the mine entrances at $600 \mathrm{~m}$ altitude by means of cable cars across the A-fiord to a floatation plant in Maarmorilik. Here, concentrates were produced, loaded onto ships and transported to smelters in Europe. For ore treatment, conventional rod/ball milling was applied to liberate $\mathrm{Pb}$ and $\mathrm{Zn}$. This was followed by froth floatation to produce separate $\mathrm{Pb}$ and $\mathrm{Zn}$ concentrates plus a waste product, tailings (Poling and Ellis, 1995). Permission for submarine disposal of tailings was given to the mining company and the tailings were subsequently discharged as a suspension in seawater and led directly into the Afiord at around 30 meters depth. In the 1970s, the annual tailings inputs from the flotation mill to the A-fiord were $4.5 \times 10^{5} \mathrm{t}$, which increased to $6 \times 10^{5} \mathrm{t}$ in the $1980 \mathrm{~s}$. During the mining period it is estimated that more than $8 \times 10^{6} \mathrm{t}$ of mine tailings containing more than $2.2 \times 10^{4} \mathrm{t} \mathrm{Pb}$ and $5 \times 10^{4} \mathrm{t} \mathrm{Zn}$ were discharged into the A-fiord (Elberling et al., 2002). As part of the mine exploitation, several waste rock dumps were established below the mine entrances in the Black Angel Mountain. One of the most polluting of these waste rock dumps, which was situated partly in the shoreline just across the A-fiord from Maarmorilik (Figure 1), was later in 1990 removed to the extent possible and the majority of the waste rock, a total of $3.2 \times 10^{5}$ tons were discharged on top of the tailings deposit in the A-fiord.

\section{Methods and instrumentation}

Numerous sample collections have been performed in Maarmorilik in the period 1972-2009. The following is a description of the sampling that is basis of the results presented in this paper. 


\section{Sampling of seawater and sediment}

Sampling of seawater was done in the A-fiord between 1975 and 2007. All samples were taken in August. Depth-specific samples were taken at $10 \mathrm{~m}$ intervals either by a metal-free water sampler or pumped up through a silicone tube. Subsequently, samples were filtered through a $0.45 \mu \mathrm{m}$ polycarbonate filter into acid-cleaned polyethylene bottles. To preserve samples, $1 \mathrm{ml}$ of Suprapure nitric acid was added to $1 \mathrm{~L}$ of seawater immediately after collection. In 2009, seawater was also collected directly from shore at 8 coastal sites (T12SV to L) (Figure 1) and given the same treatment as above. The particulate filtrates $(>0.45 \mu \mathrm{m}$ in size) were kept for subsequent analyses. Furthermore, sediment was collected from the seafloor at the same locations. In 2005, cores of sediment ( 0 to $\sim 15 \mathrm{~cm}$ ) were taken using a HAPS box corer at several locations including Station 12 in Qaamarujuk (Figure 1). The stainless steel HAPS box corer has an inner diameter of $13.5 \mathrm{~cm}$. The sediment core was cut into slices at $1 \mathrm{~cm}$ intervals and sediment that had been in contact with the HAPS was carefully removed prior to sampling. No bioturbation could be observed. Sediment samples were kept in polyethylene bags at freezing temperatures before being sent to Denmark.

\section{Sampling of seaweed}

Resident seaweed (Fucus vesiculosus or Fucus distichus) was sampled in the tidal zone directly from shore at the coastal sites (Figure 1) every 1-3 years between 1988 and 2009. Furthermore, to investigate if growth tips of seaweed sampled at the coastal sites were representative to the recent annual metal uptake, some seaweed plants living on small moveable rocks were taken from an unpolluted reference site (Site L) and transplanted to the contaminated sites and collected the following year. A number of 1 to 5 replicate seaweed samples (most often 2) were taken each time. One sample typically consists of 10 to 15 individual seaweed plants. After sampling, the seaweed was rinsed 3 times in clean water and only the fresh growth tips were kept in order to measure the most recent metal uptake. The growth tips were cut from the rest of the plants using stainless steel scissors and kept in polyethylene bags at freezing temperatures until freeze dried and homogenized in an agate mortar in Denmark prior to chemical analyses.

\section{Sampling of blue mussels}

Blue mussels (Mytilus edulis) were collected at the coastal sites at low tide in the period 1984-2009. To investigate long- and short-term uptake, both resident mussels and mussels transplanted from an unpolluted area (Site L) and collected the following year were sampled. For transplantation, 
approximately 50 mussels were placed in two small closed nets connected with a $1 \mathrm{~m}$ cord and the cord was squeezed in between a couple of large rocks for subsequent retrieval. Due to the impact of sea ice and wave activity on the shoreline, not all the transplanted mussels were successfully retrieved the following year explaining the lack of data for some years and sites. After collection, the lengths of the mussels were measured in the laboratory and the mussels divided into size classes according to their shell lengths: $4-5 \mathrm{~cm}, 5-6 \mathrm{~cm}$ etc. The mussels were counted, measured more precisely and the mean shell length calculated. One sample generally consists of 20 individual mussels. The adductors of the mussels were cut using a stainless steel scalpel and the shells opened. The mussels were then allowed to drain for a few minutes before the soft parts were removed from the shells. The soft parts of each size group were pooled into a polyethylene bag and frozen before transported to Denmark. In Denmark, samples were freeze dried and homogenized to powder in an agate mortar prior to chemical analyses. The water content of the sample was determined by weighting the sample before and after freeze drying.

\section{Chemical analyses}

Dried sediment subsamples $(500 \mathrm{mg}$ ) were digested in a mixture of $0.25 \mathrm{ml} / 0.75 \mathrm{ml} / 3 \mathrm{ml}$ Suprapure $\mathrm{HNO}_{3} / \mathrm{HCl} / \mathrm{HF}$ in Berghof bombs at $120^{\circ} \mathrm{C}$ for $4 \mathrm{~h}$, then dissolved in milliQ water and the hydrofluoric acid neutralized by boric acid. Dried and homogenized seaweed and blue mussel subsamples (300 mg) were microwave-digested (Anton Paar Multiwave 3000) in Teflon bombs in 4 $\mathrm{ml} / 4 \mathrm{ml}$ Suprapure $\mathrm{HNO}_{3} / \mathrm{milliQ}$ water. Digestion solutions of seaweed and blue mussels were diluted with milliQ water and analysed for $\mathrm{Pb}$ and $\mathrm{Zn}$ using either flame AAS (Perkin-Elmer 3030), graphite furnace AAS (Perkin-Elmer Zeeman 3030) or ICP-MS (Agilent 7500ce) at NERI, Roskilde, Denmark. Digestion solutions of sediments were diluted with milliQ water and analysed for $\mathrm{Pb}, \mathrm{Zn}$, Arsenic (As), cadmium (Cd), mercury ( $\mathrm{Hg}$ ) and aluminum (Al) using ICP-MS. The analytical methods for analyses of sediment and biota have previously been described in detail in Asmund et al. (2004). Seawater samples taken before 2007 were analysed for $\mathrm{Pb}$ and $\mathrm{Zn}$ using Anodic Stripping Voltammetry and a Hg-drop/Hg-film electrode. From 2007, seawater analyses were performed by ICP-MS after pre-concentration and elution of metals on a Chelex-100 filled micro column. In the latter, the $\mathrm{pH}$ of seawater samples, standards and reference materials were adjusted to $\mathrm{pH} 6.3$ prior to analyses.

The analytical quality of the above-mentioned analyses was checked by regularly analyzing blanks, duplicates and the certified reference materials DOLT, DORM, TORT, MESS, HISS, PACS, CASS, NASS and SLEW among others. Furthermore, the laboratory at NERI is accredited for 
analyses of elements including $\mathrm{Pb}, \mathrm{Zn}$ and $\mathrm{Cd}$ in biota, sediment and seawater with at precision of $15-20 \%$ and participates twice a year in the international QUASIMEME intercalibration program for laboratory performance.

\section{Data analyses}

Results from analyses of seawater and seaweed could be used directly for comparison of metal contamination between sites and years without any further data treatment. Data from blue mussels and sediments, however, needed some additional treatment to allow for a comparison.

For blue mussels, the transplantation of mussels has previously been shown to have a negative effect on the condition of the mussels and often results in a reduction of the mussel weight (Riget et al., 1997a). To account for that, the measured metal concentration in $\mu \mathrm{g}$ metal per g dry weight (wt.) mussel tissue was converted into $\mu \mathrm{g}$ metal per mussel by multiplying the measured concentration by the average mussel dry wt. This was done for both transplanted and resident blue mussels. Furthermore, as the metal contents in blue mussels depend on its length (Riget et al., 1997a) and since the mean lengths of the samples varied, all metal contents in mussels were normalized to the content in a $6 \mathrm{~cm}$ blue mussel using the following equation based on data from the same area (Riget et al., 1997a):

Metal_amount 6cm_mussel $_{-}=$Metal_amount ${ }_{L} \cdot\left(\frac{6}{L}\right)^{2.54}$

where Metal_amount $\mathrm{L}_{\mathrm{L}}$ is the metal amount in a blue mussel with a mean shell length of $\mathrm{L}$. Most often, the corrections made to mussel contents were minimal as the preferred size group of 5-6 $\mathrm{cm}$ or alternatively 6-7 $\mathrm{cm}$ having a mean shell length close to $6 \mathrm{~cm}$ could be sampled. In some cases, however, only mussels with a mean length less than $5 \mathrm{~cm}$ or more than $7 \mathrm{~cm}$ could be found at the site (see Supplementary data section for a list of all blue mussel data).

For sediments, the concentrations of $\mathrm{Pb}, \mathrm{Zn}, \mathrm{As}, \mathrm{Cd}$ and $\mathrm{Hg}$ are expressed as the ratio of these elements to $\mathrm{Al}$ in order to allow for a comparison of metal contents in sediment within the sediment profile at Station 12 and between the coastal sites. The normalization to $\mathrm{Al}$ was done to minimize the effect of grain size on the metal concentrations (e.g. Perner et al., 2010) as the sediment samples were not size-fractionated prior to analyses (see Supplementary data section for a list of all sediment data).

Time trends of $\mathrm{Pb}$ and $\mathrm{Zn}$ in seaweed and blue mussels were investigated statistically following the ICES (International Council for the Exploration of the Sea) temporal trend assessment procedure (Nicholson et al., 1998). In short, the log-mean concentration is used as the annual index value. The 
total variation over time is partitioned into a linear and a non-linear component. Linear regression analysis is applied to describe the linear component and a LOESS smoother (locally weighted quadratic least-squares regression smoothing) with a window width of 7 years is applied to describe the non-linear component. The linear and non-linear components are tested by means of an analysis of variance. The theory behind the use of smoothers in temporal trend analyses is described in detail by Fryer and Nicholson (1999). A significance level of 5\% was applied.

\section{Results and discussion}

Trends in seawater in the A-fiord and Q-fiord

The results from analyses of seawater taken in the A-fiord in autumn during the period 1975-2008 are shown in Figure 2. In autumn, the water in the A-fiord is distinctly stratified and a pycnocline is observed at approximately 25 m's depth (Johansen et al., 2008). In Figure 2, Pb and Zn concentrations are presented as mean values above and below the pycnocline. During the mining period, bottom water in the A-fiord was heavily contaminated by $\mathrm{Pb}$ and $\mathrm{Zn}$ with concentrations up to $440 \mu \mathrm{g} \mathrm{L}^{-1}$ and $791 \mu \mathrm{g} \mathrm{L}^{-1}$, respectively. In the surface water, maximum concentrations during the mining period were 30-50 times lower than in the bottom water with $\mathrm{Pb}$ and $\mathrm{Zn}$ concentration up to $12 \mu \mathrm{g} \mathrm{L}^{-1}$ and $16 \mu \mathrm{g} \mathrm{L}{ }^{-1}$, respectively. The very contaminated bottom water in the A-fiord during the mining period is primarily considered the result of dissolution of $\mathrm{Pb}$ and $\mathrm{Zn}$ from the tailings after they were discharged but before they settled on the bottom of the A-fiord (Asmund 1992b; Poling and Ellis, 1995). The elevated concentrations of metals in the surface water of the A-fiord are mainly regarded as a consequence of mixing of surface water with metal-rich bottom water during the winter period (Johansen et al., 2008).

In 1990, when the mine closed and 320,000 tons of waste rock was dumped in the A-fiord, a peak in $\mathrm{Pb}$ and $\mathrm{Zn}$ concentrations in the surface water and in $\mathrm{Zn}$ in the bottom water of the A-fiord was observed. In contrast to $\mathrm{Zn}$, the $\mathrm{Pb}$ concentration in the bottom water was lower in 1990 compared to the previous years (Figure 2). The relatively higher content of $\mathrm{Zn}$ in seawater in 1990 compared to $\mathrm{Pb}$ is considered the result of a higher release of $\mathrm{Zn}$ relative to $\mathrm{Pb}$ (by a factor of 12 ) from the waste rock (Asmund, 1992a). After 1990, Pb concentrations decreased abruptly in the A-fiord and during the most recent measurements in 2008 , concentrations of $0.086 \mu \mathrm{g} \mathrm{Pb} \mathrm{L}^{-1}$ in surface water and $0.307 \mu \mathrm{g} \mathrm{Pb} \mathrm{L}^{-1}$ in bottom water were measured. Mean $\mathrm{Pb}$ concentrations in the bottom water during the period 1995-2008 were reduced to about 1/1000 of those in 1988-89 and Pb levels in the surface water in 2008 were near $\mathrm{Pb}$ concentrations in uncontaminated seawater (about a factor of 2 higher than $\mathrm{Pb}$ at Site T37; Table 1). $\mathrm{Zn}$ levels in the A-fiord have not decreased as much as $\mathrm{Pb}$. In 
2008 , the $\mathrm{Zn}$ concentration in bottom water was $27 \mu \mathrm{g} \mathrm{L}^{-1}$, which is only about 10 times lower than in 1988-89 and 50-100 times higher than in uncontaminated near-shore seawater (Site T37; Table 1). Similarly, the $\mathrm{Zn}$ concentration in surface water in the A-fiord was $6.7 \mu \mathrm{g} \mathrm{L}^{-1}$ in 2008 , which is about a factor of 10-50 higher than in uncontaminated near-shore seawater (Table 1). The relative high concentrations of $\mathrm{Zn}$ in seawater in the A-fiord indicate that there is still a significant ongoing release of $\mathrm{Zn}$ from minerals in the buried tailings and waste rock (presumably $\mathrm{ZnS}$ ) deposited on the bottom of the A-fiord while a release of $\mathrm{Pb}$ from $\mathrm{Pb}$-containing minerals can probably be considered negligible. The observed increase in $\mathrm{Zn}$ concentrations in bottom and surface water from 2002 to 2008 (Figure 2) is not readily explained but may reflect a decrease in water exchange between the A- and Q-fiord at the time.

In August 2009, seawater samples were taken directly from shore at several coastal sites in the Qfiord and the metal concentrations are shown in Table 1. At Site T12SV, situated in the former waste rock dump area, near-shore seawater contained high dissolved $\mathrm{Pb}$ and $\mathrm{Zn}$ concentrations (0.46 and $2.4 \mu \mathrm{g} \mathrm{L}^{-1}$, respectively). This is twice the $\mathrm{Pb}$ concentration and $1 / 10$ of the $\mathrm{Zn}$ concentration at the bottom of the A-fiord. These concentrations are high considering that it is a coastal tidal zone where considerable mixing of seawater takes place. At the remaining sites, $\mathrm{Zn}$ concentrations were at approximately the same level and close to uncontaminated seawater (Site T37) while Pb concentrations may be slightly elevated at Site T22 to T36. It has to be noted that the water samples above represent only conditions during the short moment of sampling and may not be representative to conditions during a longer period of time. However, the results indicate that the remains of the former waste rock dump near Site T12SV are still a major source of $\mathrm{Pb}$ and $\mathrm{Zn}$ contamination in the area.

\section{Trends in sediments in the $Q$-fiord}

A sediment core was taken at Station 12 in the middle of the Q-fiord just outside from Maarmorilik in 2005 and the concentrations of $\mathrm{Pb}, \mathrm{Zn}, \mathrm{As}, \mathrm{Cd}$ and $\mathrm{Hg}$ normalized to $\mathrm{Al}$ in the sediments can be seen in Figure 3. Elevated concentrations of all these elements were observed in sediments that were deposited during the mining period and in the years after but concentrations have decreased in recent years. However, the concentrations of $\mathrm{Pb}, \mathrm{Zn}, \mathrm{As}$ and $\mathrm{Hg}$ in the uppermost sediment layer at Station 12 were still elevated in 2005 compared to pre-mining levels. Only Cd had decreased to premining levels. It is interesting to note that $\mathrm{Pb}, \mathrm{Zn}, \mathrm{As}$ and $\mathrm{Hg}$ concentrations peaked some years after the mine closure in 1990, which may be the result of a slow long-term sediment transport within the Q-fiord (Elberling et al., 2002). The contaminated sediments observed in the middle of 
the Q-fiord is likely to be the result of both a dispersal of fine-grained particles coming from the land-based waste rock dumps as well from metals dissolved from the tailings and waste rock, which were later bound to natural sediment. During the mining period, it was estimated that about equal amounts of both $\mathrm{Pb}$ and $\mathrm{Zn}$ were released to the Q-fiord from the waste rock dumps (mainly as particles) and as dissolved metals from the tailings, respectively (Asmund, 1992b).

In 2009, near-shore seafloor sediments were sampled together with particulate filtrates $(>0.45 \mu \mathrm{m}$ in size) of seawater from several coastal sites in the Q-fiord (Table 1). The $\mathrm{Pb}$ and $\mathrm{Zn}$ contents normalized to $\mathrm{Al}$ were (except from near-shore sediment at Site T12SV) lower than measured in sediment at Station 12 in the middle of the Q-fiord. The normalized $\mathrm{Pb}$ and $\mathrm{Zn}$ contents decreased in both near-shore sediments and particulate filtrates with increasing distance to the mine. At Site T12SV and T22, closest to the mine, both near-shore sediments and particulate filtrates contained elevated $\mathrm{Pb}$ contents (normalized to $\mathrm{Al}$ ) compared to the rest of the sites. Elevated $\mathrm{Zn}$ contents in near-shore sediments and particulate filtrates were measured in a larger area covering the sites T12SV and T22, but also the more distant sites T25, T29 and T30. The results above indicate that near-shore sediments and particles suspended in the seawater at several of the coastal sites were still metal-contaminated almost two decades after mine closure.

\section{Initial seaweed experiments}

The seaweed species Fucus vesiculosus was preferred when sampling seaweed in Maarmorilik. However, at some sites and during some years it was not possible to find this species and the species Fucus distichus was sampled instead. The two different species look very similar and first it was important to find out whether the metal contents contained in the growth tips of these two species provided similar results. Therefore, both species were sampled at the same sites during some years and the results compared. The results for $\mathrm{Pb}$ in growth tips of the two species can be seen in Figure 4a. The results show that there is no systematic difference in metal concentration in growth tips between the two species in Maarmorilik. A similar conclusion was found in a seaweed study from the Nuuk fiord in Southwest Greenland (Riget et al., 1997b).

Next, we investigated whether growth tips of resident seaweed in Maarmorilik represent the uptake of metals within the recent year. To do that, seaweed plants were collected at an uncontaminated site (Site L) and transplanted to various sites in Maarmorilik and collected the following year. The metal concentrations in growth tips of transplanted seaweed were then compared to resident seaweed and the results for $\mathrm{Pb}$ can be seen in Figure $4 \mathrm{~b}$. Data shows no systematic difference between transplanted and resident seaweed indicating that metal contents in growth tips of resident 
seaweed in Maarmorilik can be regarded as an integrated measure of the recent annual uptake of metals. Uptake of metals in seaweed is regarded as a relative measure of the dissolved metal concentration within the surrounding seawater (Rainbow, 1995; Larsen et al., 2001). Consequently, it was concluded that the variations in metal concentration measured in growth tips of resident Fucus vesiculosus or Fucus distichus species at the various sites and years in Maarmorilik could be treated as a relative measure of the recent annual variation in dissolved metal concentrations at the sampling sites.

\section{Metal contamination of seaweed in Maarmorilik and temporal and spatial trends}

Metal contamination of seaweed related to mining in Maarmorilik is shown in Table 2. Here $\mathrm{Pb}, \mathrm{Zn}$, As, $\mathrm{Cd}$ and $\mathrm{Hg}$ concentrations in seaweed growth tips at an uncontaminated site (Site L) versus at a high-impact site (Site T12SV) sampled in 2009. Of the elements analysed, $\mathrm{Pb}$ and $\mathrm{Zn}$ were the most elevated with factors of 15-30 times higher concentrations measured at Site T12SV indicating that $\mathrm{Pb}$ and $\mathrm{Zn}$ are the elements of main importance justifying the focus on $\mathrm{Pb}$ and $\mathrm{Zn}$ in the following. The $\mathrm{Pb}$ and $\mathrm{Zn}$ concentrations in seaweed during the period 1988-2009 in Maarmorilik are shown in Figure 5 for three contaminated sites with increasing distances to the mine. At all sites, the highest $\mathrm{Pb}$ and $\mathrm{Zn}$ concentrations in seaweed during the period 1988-2009 were measured in 1990.

Seaweed at Site T12SV contained the most $\mathrm{Pb}$ and $\mathrm{Zn}$ with concentrations up $84 \mu \mathrm{g} \mathrm{g}^{-1}$ and $363 \mu \mathrm{g}$ $\mathrm{g}^{-1}$ dry wt., respectively. The high concentrations measured in 1990 are considered due to the removal of the old shore-line waste rock dump near Site T12SV and subsequently the discharge of waste rock into the A-fiord releasing $\mathrm{Pb}$ and $\mathrm{Zn}$ in the process. An additional factor was the processing of old oxidized ore and the following release of tailings with a high soluble $\mathrm{Pb}$ content during the last months before mine closure. It is believed that the discharge of waste rock is the main explanation for the high $\mathrm{Zn}$ concentrations in 1990 and the processing of old oxidized ore is the main reason for the high $\mathrm{Pb}$ concentrations in 1990 (Asmund, 1992a; Asmund, 1992b). Since 1990, seaweeds at contaminated sites in Maarmorilik area have shown decreasing trends in $\mathrm{Pb}$ and $\mathrm{Zn}$ concentrations (Table 3). This applies to all sites (a total of 21) within a distance of 20 $\mathrm{km}$ from the mine (Schiedek et al., 2009). At most sites the trends were significant at a $5 \%$ significance level and trends were both indicated by log-linear trends (exponential decreasing) and non-linear trends (Table 3). The dominant trend, however, was log-linear when considering all seaweed sites near Maarmorilik (Schiedek et al., 2009). The decreasing trends in $\mathrm{Pb}$ and $\mathrm{Zn}$ contamination in seaweed from 1990 to 2009 are considered the result of a decrease in dissolution 
of $\mathrm{Pb}$ and $\mathrm{Zn}$ from the tailings and waste rock discharged in the A-fiord and from the remaining waste rock left on the steep mountain sides near Maarmorilik.

In 2009, when the most recent sample was taken, $\mathrm{Pb}$ and $\mathrm{Zn}$ concentrations in seaweed within an area of $12 \mathrm{~km}$ from Maarmorilik were still elevated by factors of 7-30 for $\mathrm{Pb}$ and 4-16 for $\mathrm{Zn}$

(Figure 6). The elevated levels of $\mathrm{Pb}$ and $\mathrm{Zn}$ in seaweed correspond partly with the $\mathrm{Pb}$ and $\mathrm{Zn}$ levels measured in seawater at the same sites in 2009 (Table 2). The elevation of $\mathrm{Pb}$ and $\mathrm{Zn}$ in seaweed at Site T12SV in 2009 was consistent with elevated dissolved $\mathrm{Pb}$ and $\mathrm{Zn}$ in seawater at measured at Site T12SV. Similarly, elevated Pb concentrations in seaweed from Site T22 to T36 were consistent with higher dissolved $\mathrm{Pb}$ in seawater sampled in 2009 at those sampling sites compared to Site T37 further away from Maarmorilik (Site L was not measured). In contrast, however, elevated Zn concentrations in seaweed from Site T22 to T36 were not reflected in measureable elevated dissolved $\mathrm{Zn}$ concentrations in seawater at those sites. The observed difference is likely due to the fact that metal concentrations in seaweed growth tips represent a complex time-integrated measure of the dissolved metal concentrations in the seawater during the whole growing season while the seawater samples represent only conditions during the short period of sampling.

\section{Metal contamination of blue mussels in Maarmorilik and temporal and spatial trends}

The uptake of $\mathrm{Pb}, \mathrm{Zn}, \mathrm{As}, \mathrm{Cd}$ and $\mathrm{Hg}$ in blue mussels near Maarmorilik is exemplified in Table 2. This table shows element concentrations in blue mussels transplanted from an uncontaminated reference site (Site L) in 2008 to the most contaminated site in Maarmorilik (Site T12SV) and collected in 2009. The results show that only $\mathrm{Pb}$ and $\mathrm{Zn}$ were elevated after one year of transplantation (by a factor of 25 for $\mathrm{Pb}$ and $\sim 2$ for $\mathrm{Zn}$ ) indicating that $\mathrm{Pb}$ and $\mathrm{Zn}$ are the elements of main importance with respect to metal contamination of blue mussels in Maarmorilik.

$\mathrm{Pb}$ and $\mathrm{Zn}$ concentrations in resident and transplanted blue mussels from three contaminated sites in Maarmorilik during the period 1985-2009 are shown in Figure 7. At all sites, the highest $\mathrm{Pb}$ and $\mathrm{Zn}$ concentrations in mussels during the period were measured in 1989 and 1990. Resident blue mussels at Site T12SV contained the most $\mathrm{Pb}$ and $\mathrm{Zn}$ with concentrations up to 2,650 $\mu \mathrm{g} \mathrm{g}^{-1}$ dry wt. $\mathrm{Pb}$ and 1,190 $\mu \mathrm{g} \mathrm{g}^{-1}$ dry wt. Zn. This corresponds to 2,530 $\mu \mathrm{g} \mathrm{Pb}$ and $970 \mu \mathrm{g} \mathrm{Zn}$ in a blue mussel with a shell length of $6 \mathrm{~cm}$. According to previous studies, suspension feeders such as blue mussels take up metals bound to particulate matter and food particles as well as metals in dissolved form within the seawater (Rainbow, 1995; Larsen et al., 2001). Consequently, the high $\mathrm{Pb}$ and $\mathrm{Zn}$ concentrations in 1989 and 1990 are considered the result of both a higher dispersion of dissolved and particle-bound $\mathrm{Pb}$ and $\mathrm{Zn}$ at that time as a consequence of removal and subsequently disposal of 
the former waste rock dump into the A-fiord as well as disposal of mine tailings with a higher soluble $\mathrm{Pb}$ content during the last months of mine operation.

After 1990, resident blue mussels at contaminated sites in Maarmorilik area have shown decreasing trends in $\mathrm{Pb}$ and $\mathrm{Zn}$ concentrations (Table 3). This applies to all blue mussel sites (a total of 19) within a distance of $35 \mathrm{~km}$ from the mine (Schiedek et al., 2009). For transplanted mussels, decreases in $\mathrm{Pb}$ contents (and $\mathrm{Zn}$ at the site nearest to the mine) were also observed after 1990. At the more distant sites, $\mathrm{Zn}$ contamination in mussels was very low or negligible during the period when transplantation of mussels was conducted. Time trends for resident blue mussels after 1990 were significant at all sites at a $5 \%$ significance level and trends were predominately log-linear (exponential decreasing) (Table 3). The decrease in $\mathrm{Pb}$ and $\mathrm{Zn}$ in resident and transplanted blue mussels is considered the result of a decrease in dissolution of $\mathrm{Pb}$ and $\mathrm{Zn}$ from tailings and waste rock in the A-fiord (now buried under a layer of natural sediment) as well as a decrease in outwash of dissolved and particle-bound $\mathrm{Pb}$ and $\mathrm{Zn}$ from the remaining land-based waste rock dumps near Maarmorilik. For resident mussels, the decrease in $\mathrm{Pb}$ and $\mathrm{Zn}$ is also influence by a disappearance of old mussels in the size group preferred and the emergence of new generations of mussels that have been exposed to lower concentrations.

In 2009, $\mathrm{Pb}$ contents in transplanted blue mussels within an area of $12 \mathrm{~km}$ from Maarmorilik were still elevated by factors of 2-25 after one year of transplantation (Figure 8). In contrast, relative $\mathrm{Zn}$ levels were much lower and were less than a factor of 2 higher than the initial content for all sites (Figure 8). The limited contamination by $\mathrm{Zn}$ in blue mussels is in contrast to seaweed, which contains elevated concentrations of $\mathrm{Zn}$ in a larger area around Maarmorilik. The observed differences between $\mathrm{Zn}$ in blue mussels and seaweed may be explained by differences in sources of metal uptake between the two species i.e. metal uptake by blue mussels may be more controlled by particle-bound metals than dissolved metals. An alternative explanation is that blue mussels may have a greater capacity to regulate the internal accumulation of $\mathrm{Zn}$ compared to seaweed, $\mathrm{Zn}$ being an essential nutritional element to biota in contrast to $\mathrm{Pb}$.

\section{Transplanted versus resident blue mussels}

Transplanted blue mussels were used for monitoring recent metal contamination at the coastal sites in addition to sampling of resident blue mussels. A previous study from Maarmorilik has shown that once metals such as $\mathrm{Pb}$ and $\mathrm{Zn}$ are taken up in blue mussels, these are released at a very slow rate should the environmental conditions improve (Riget et al, 1997a). Furthermore, blue mussels grow relatively slowly in arctic waters and a blue mussel with the preferred shell length of $6 \mathrm{~cm}$ is 
likely to be approximately 12 years old (Theisen, 1973). Consequently, resident blue mussels did not seem adequate for monitoring annual variations in seawater contamination in a situation with decreasing contamination. Thus, blue mussels were transplanted to selected sites from an uncontaminated site (Site L) and collected the following year. The differences between the $\mathrm{Pb}$ and $\mathrm{Zn}$ contents in transplanted versus resident blue mussels at typical sites can be seen in Figure 7. The $\mathrm{Pb}$ and $\mathrm{Zn}$ contents were consistently lower in transplanted mussels after one year of transplantation compared to resident mussels. The largest differences between transplanted and resident mussels were observed just after the mining period when the change in contamination rate was highest and the concentrations approached each other towards the end of the monitoring period. Also, it is notable that the $\mathrm{Pb}$ content in transplanted mussels at Site T17A (Figure 7) in 1985 were about 4 times higher than in 1992 while the resident mussels contained approximately the same amount. The differences between $\mathrm{Pb}$ and $\mathrm{Zn}$ in transplanted versus resident blue mussels after 1990 show that $\mathrm{Pb}$ and $\mathrm{Zn}$ are released from the resident mussels at a very slow rate. It also shows that transplantation of blue mussels is an adequate way to monitor short-term (annual) changes in seawater metal contamination in contrast to resident mussels. This is at least the case for monitoring metals such as $\mathrm{Pb}$ and $\mathrm{Zn}$ in arctic blue mussels in a situation where the contamination is decreasing.

\section{Contamination sources, processes and "lessons learned" in Maarmorilik}

During the mining period from 1973 to 1990, the major inputs of mine-related metals to the marine environment in Maarmorilik came from disposal of mine tailings and later waste rock into the small partly-enclosed A-fiord (Asmund, 1992b). The A-fiord is separated from the outer Q-fiord by a shallow submarine sill and an almost stagnant water mass is created below the sill during summer. This presumably makes the A-fiord an ideal trap for suspended particles such as mine tailings, which at the time when mining was commenced was thought to contain insoluble metal compounds. However, as studies later revealed, the tailings contained heavy metals including $\mathrm{Pb}, \mathrm{Zn}$ and $\mathrm{Cd}$ bound in chemical forms that were indeed soluble in the ambient seawater. The main minerals of the tailings were calcite, dolomite and pyrite but it was indicated that most of the $\mathrm{Zn}$ and $\mathrm{Cd}$ were contained in the mineral sphalerite $(\mathrm{ZnS}) . \mathrm{Pb}$ was mainly contained in minerals other than sulphides, probably carbonates or sulphates (Loring and Asmund, 1989; Asmund, 1992b). Studies showed that metals dissolved during the dilution of the tailings with the seawater and the simultaneous decrease of $\mathrm{pH}$ from approximately 10 to 8 (Asmund, 1992b). Seasonal mixing of the water column in the A-fiord was later found to take place during winter as a result of freezing of the 
surface water and an inflow of water between the A-fiord and Q-fiord (Møller, 1984). The complete vertical mixing of water and increased water exchange between the two fiords increased the dispersion of dissolved metals as well as fine suspended tailings particles from the A-fiord to the Qfiord. Also, the mixing of water led to increased oxidation- and dissolution-potentials of the tailings particles in suspension as well as the tailings and waste rock situated on the bottom of the A-fiord (Elberling et al., 2002). During the mining period, the main process responsible for the input of dissolved metals to the marine environment in Maarmorilik was considered the dissolution of mine tailings. The dissolution process occurred mainly after discharge but before settling of the tailings close to the outlet point (Asmund, 1992b). This was shown by an abrupt decrease in $\mathrm{Pb}$ concentrations in the bottom water of the A-fiord after the mine closed down in 1990 and the last produced tailings had settled. While the main input of dissolved metals came from the tailings, the waste rock dumps were significant sources of contamination of the intertidal zones (Asmund, 1992b).

After 1990, the Pb concentrations decreased abruptly in the bottom water of the A-fiord while the $\mathrm{Zn}$ concentrations did not decrease to the same extent. During the last measurements in 2008, $\mathrm{Zn}$ levels were still 50-100 times higher than in uncontaminated seawater. This indicates that considerable amounts of $\mathrm{Zn}$ were and still are released from the buried mine waste in the A-fiord while the dissolution of $\mathrm{Pb}$ are probably negligible. In contrast, the abrupt decrease in $\mathrm{Pb}$ concentration in water within the A-fiord was not reflected in a similar abrupt decrease in $\mathrm{Pb}$ contamination in seaweed and blue mussels. This indicates that the main sources of $\mathrm{Pb}$ contamination of the marine environment in Maarmorilik have likely shifted from the tailings disposed into the A-fiord to outwash of dissolved and particle-bound $\mathrm{Pb}$ from the land-based waste rock dumps as well as from land-deposited dust that was spread during the mining period. Given the time trends for $\mathrm{Pb}$ and $\mathrm{Zn}$ in seaweed and blue mussels, it seems likely that elevated levels of $\mathrm{Pb}$ and $\mathrm{Zn}$ in seaweed and blue mussels will still be measured for at least 50 more years near Maarmorilik, even if no new mining activity is commenced.

In the Maarmorilik case, poor environmental studies and decision-making led to significant metal contamination of the marine environment near Maarmorilik. Several lessons can be learned from that, including those listed below. First of all, if mine waste is going to be disposed into the sea, very detailed studies of how the waste will react in that environment has to be made prior to disposal because once it is disposed it is nearly impossible to retrieve. Studies prior to disposal must include representative waste material (tailings/waste rock) obtained from a pilot project prior to the mine operation subjected to the conditions in which it is going to be disposed (using representative 
seawater). More rough tests, such as leach tests using acetic acid will also provide valuable results. The effects of different redox conditions on the chemical behavior of the mine waste have to be included in the tests as well as a thorough understanding of the hydrological conditions all year round at the disposal-site as these may effect the mobilization and dispersion of contaminants. Bioaccumulation studies are useful tools to reveal how different organisms react to the given exposure. During mining activities, attention must be given to minimize the generation and dispersal of dust as dust particles may remain in the terrestrial environment for several decades after the initial deposition. Finally, chemically reactive waste rock must be kept away from the tidal zone and if at all possible transported to a confined area as part of the mining process and subsequently covered e.g. with chemically inert rock material such as the marble/dolomite found in Maarmorilik. The remains of a former land-based waste rock dump is still a major contaminant source two decades after mine closure, which shows that once large amounts of waste rock are dumped in an environmentally unsafe manner, it is extremely difficult to remediate afterwards probably due to finer grained particles remaining on site.

\section{Conclusion}

This study assessed the present environmental state adjacent to the former $\mathrm{Pb}-\mathrm{Zn}$ mine in Maarmorilik, West Greenland. Despite the two decades that have passed since mine closure; seawater, sediment and biota, including seaweed and blue mussels are still contaminated with $\mathrm{Pb}$ and $\mathrm{Zn}$ related to the past mining operation. This reveals a slow recovery of this arctic fiord system to mining pollution. Specifically, it was shown that 12 kilometers from the mine, seaweed and blue mussels still contain elevated concentrations of $\mathrm{Pb}$ (and in seaweed also $\mathrm{Zn}$ ). During the mining period, the primary source of contamination was considered the dissolution of metals from mine tailings that were discharged into the small fiord Affarlikassaa near Maarmorilik. Later, following the settling of tailings on the bottom of Affarlikassaa and the burial of these with natural sediment, the main sources of $\mathrm{Pb}$ contamination of the marine environment in Maarmorilik have likely changed. Remaining land-deposited waste rock, especially the residues of an old large-scale waste rock dump as well as outwash $\mathrm{Pb}$-contaminated dust generated during the mining period are now considered the dominant sources of $\mathrm{Pb}$ contamination in Maarmorilik. The contamination by $\mathrm{Zn}$, however, still seems to be considerably influenced by a release of $\mathrm{Zn}$ from the waste materials at the bottom of Affarlikassaa.

\section{References}


Asmund, G., 1980. Water movements traced by metals dissolved from mine tailings deposited in a fjord in Northwest Greenland. In: Freeland, H.J., Framer, D.M, Levings, C.D. (Eds.), Fjord Oceanography. Plenum Press, New York and London, pp. 347-353.

Asmund, G., 1992a. Lead and zinc pollution from dumping of waste rock from lead-zinc mining. In: Bandopadhyay, S., Nelson, M.G. (Eds.), Mining in the Arctic. A.A. Balkema, Rotterdam, pp. 105-112.

Asmund, G., 1992b. Pollution from the marine tailings disposal at the lead-zinc mine at Maarmorilik, West Greenland. Singhal, R.K., Mehrotra, A.K., Fytas, K., Collins, J.L. (Eds.), Environmental Issues and Management of Waste in Energy and Mineral Production. A.A. Balkema, Rotterdam, pp. 587-594.

Asmund, G., Vorkamp, K., Backus, S., Comba, M., 2004. An update of analytical methods, quality assurance and quality control used in the Greenland AMAP programme 1999-2002. Science of the Total Environment 331, 233-245.

Cairrao, E., Pereira, M.J., Pastorinho, M.R., Morgado, F., Soares, A.M.V.M., Guilhermino, L., 2007. Fucus spp. as a mercury contamination bioindicator in coastal areas (Northwestern Portugal). Bulletin of Environmental Contamination and Toxicology 79 (4), 388-395.

Elberling, B., Asmund, G., Kunzendorf, H., Krogstad, E.J., 2002. Geochemical trends in metalcontaminated fiord sediments near a former lead-zinc mine in West Greenland. Applied Geochemistry 12, 493-502.

Escher, A., Pulvartaft, T.C.R., 1976. Rinkian mobile belt of West Greenland. In: Escher, A., Watt, W.S. (Eds.), Geology of Greenland, Geological Survey of Greenland, Copenhagen, pp. 105-119.

Fryer, R.J., Nicholson, M.D., 1999. Using Smoothers for comprehensive assessments of contaminant time series in marine biota. ICES Journal of Marine Science 56, 779-790.

Johansen, P., Asmund, G., Riget, F., Johansen, K., 2008. Environmental monitoring at the lead-zinc mine in Maarmorilik, Northwest Greenland, 2007. National Environmental Research Institute, 
Aarhus University. NERI Technical Report No. 684. 54 p. (available at http://www.dmu.dk/Pub/FR684.pdf).

Larsen, T.S., Kristensen, J.A., Asmund, G., Bjerregaard, P., 2001. Lead and zinc in sediments and biota from Maarmorilik, West Greenland: an assessment of the environmental impact of mining wastes on an Arctic fjord system. Environmental Pollution 114, 275-283.

Loring, D.H., Asmund, G., 1989. Heavy metal contamination of a Greenland Fiord system by mine wastes. Environmental Geology and Water Sciences 14 (1), 61-71.

Møller, J.S., 1984. Hydrodynamics of an arctic fiord. Thesis: Institute of Hydrodynamics and Hydraulic Engineering (ISVA). Technical University of Denmark. Lyngby, Denmark. 197 p.

Nicholsen, M.D., Fryer, R.J., Larsen, J.R., 1995. Temporal trend monitoring: Robust method for analysing contaminant trend monitoring data. ICES Techniques in Marine Environmental Sciences 20. International Council for the Exploration of the Sea (ICES). Copenhagen, Denmark. 29 p.

O’Connor, T.P., Lauenstein, G.G., 2006. Trends in chemical concentrations in mussels and oysters collected along the US coast: Update to 2003. Marine Environmental Research 62, 261-285.

Perner, K., Leipe, T.H., Dellwig, O., Kuijpers, A., Mikkelsen, N., Andersen, T.J., Harff, J., 2010. Contamination of arctic fjord sediments by $\mathrm{Pb}-\mathrm{Zn}$ mining at Maarmorilik in central West Greenland. Marine Pollution Bulletin 60 (7), 1065-1073.

Poling, G.W., Ellis, D.V., 1995. Importance of geochemistry: The Black Angel Lead-Zinc Mine, Greenland. Marine Georesources and Geotechnology 13, 101-118.

Riget, F., Johansen, P., Asmund, G., 1997a. Uptake and release of lead and zinc by blue mussels. Experience from transplantation experiments in Greenland. Marine Pollution Bulletin 34 (10), 805815.

Riget, F., Johansen, P., Asmund, G., 1997b. Baseline levels and natural variability of elements in three seaweed species from West Greenland. Marine Pollution Bulletin 34 (10), 805-815. 
Rainbow, P.S., 1995. Biomonitoring of heavy metal availability in the marine environment. Marine Pollution Bulletin 31, 183-192.

Schiedek, D., Asmund, G., Johansen, P., Riget, F., Johansen, K., Strand, J., Mølvig, S., 2008. Environmental monitoring at the former lead-zinc mine in Maarmorilik, Northwest Greenland, in 2008. National Environmental Research Institute, Aarhus University. NERI Technical Report No. 737. 70 p. (available at http://www.dmu.dk/Pub/FR737.pdf).

Theisen, B.F., 1973. The growth of Mytilus edulis L. (bivalvia) from Disko and Thule district, Greenland. Ophelia 12, 59-77.

Thomassen, B., 2003. The Black Angel lead-zinc mine at Maarmorilik in West Greenland. Geology and Ore - Exploration and mining in Greenland no. 2 (available at http://www.geus.dk/minex/go02_2ed.pdf).

Torres, M.A., Barros, M.P., Campos, S.C.G., Pinto, E., Rajamani, S., Sayre, R.T., Colepicolo, P., 2008. Biochemical biomarkers in algae and marine pollution: A review. Ecotoxicology and Environmental Safety 71 (1), 1-15.

\section{Tables}

Table 1. $\mathrm{Pb}$ and $\mathrm{Zn}$ concentrations in seawater filtered to $<0.45 \mu \mathrm{m}$ in size; in the remaining particulate filtrate; and in near-shore sediment sampled at various sites near Maarmorilik in 2009. In the filtrate and sediment, the $\mathrm{Pb} / \mathrm{Al}$ and $\mathrm{Zn} / \mathrm{Al}$ ratios are also shown in order to normalize the $\mathrm{Pb}$ and $\mathrm{Zn}$ contents against variations in grain size.

Table 2. $\mathrm{Pb}, \mathrm{Zn}, \mathrm{As}, \mathrm{Cd}$ and $\mathrm{Hg}$ concentrations ( $\mu \mathrm{g} \mathrm{g} \mathrm{g}^{-1}$ dry wt.) in growth tips of seaweed and in blue mussel tissue in mussels with a shell length of 5-6 cm sampled in 2009. Results are given for seaweed samples collected at an uncontaminated reference site (Site L) and at a high-impact site (Site T12SW) and for blue mussels from Site L before and after one year of transplantation at Site T12SV. 
Table 3. Results of the temporal trend analyses of $\mathrm{Pb}$ and $\mathrm{Zn}$ in seaweed and in resident and transplanted blue mussels at three sites in Maarmorilik with increasing distances to the mine/former waste rock dump area sampled during the period after mining (1991-2009). Site T12SW (a) is situated in the former waste rock dump area; Site T17A (b) and Site T36 (c) are located about 2 and $12 \mathrm{~km}$ away from Maarmorilik, respectively (Figure 1). Significance at the 5\% level is shown by "sign" and non-significance by "_." for both the log-linear trend and the non-linear trend components. The results of the trend analyses can be interpreted as follows: 1) Both log-linear and

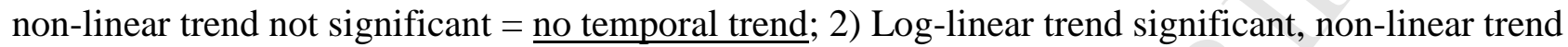
not significant $=\underline{\log \text {-linear trend }}($ exponential trend); 3 ) Both log-linear trend and non-linear trend significant $=\underline{\text { non-linear trend; }}$ 4) Log-linear trend not significant, non-linear trend significant $=\underline{\text { non- }}$ linear trend. Furthermore, the overall annual change in percentage during the period is given.

\section{Figures}

Figure 1. Map of Maarmorilik and the surrounding area with the location of the sampling sites.

Figure 2. Mean $\mathrm{Pb}$ and $\mathrm{Zn}$ concentrations in surface water (0-20 m depth) (a) and in bottom water (30-60 m depth) (b) in Affarlikassaa during autumn (august) from 1975 to 2008.

Figure 3. Variations of $\mathrm{Pb}, \mathrm{Zn}, \mathrm{As}, \mathrm{Cd}$ and $\mathrm{Hg}$ in sediment sampled in the Qaamarujuk fiord in 2005 at Station 12, just outside Maarmorilik. The concentrations have been normalized to $\mathrm{Al}$ in order to compensate for variations in grain size. The dotted lines indicate the approximate position of layers sedimented in 1973 and 1990 based on sedimentation rates and ${ }^{210} \mathrm{~Pb}$ dating of sediments at the same site performed by Elberling et al. (2002).

Figure 4. $\mathrm{Pb}$ concentrations in growth tips from the seaweed species Fucus distichus versus Fucus vesiculosus (a); and $\mathrm{Pb}$ concentrations in growth tips from resident seaweed versus growth tips from seaweed transplanted from an unpolluted area (Site L) and collected at the site one year after (b).

Figure 5. $\mathrm{Pb}$ and $\mathrm{Zn}$ concentrations in growth tips from seaweed (Fucus distichus or Focus vesiculosus) at three sites in Maarmorilik with increasing distances to the mine/former waste rock dump sampled from 1988 to 2009. 
Figure 6. $\mathrm{Pb}$ and $\mathrm{Zn}$ concentrations in growth tips from seaweed (Fucus distichus or Focus vesiculosus) at five sites in Maarmorilik in 2009. The distances from the former waste rock dump area are shown in parentheses.

Figure 7. $\mathrm{Pb}$ and $\mathrm{Zn}$ contents in resident and transplanted blue mussels at three sites in Maarmorilik with increasing distances to the mine/former waste rock dump sampled from 1985 to 2009. Transplanted mussels were collected at an unpolluted reference site (Site L), transplanted in nets to the three sites and sampled the year after. Since the mussel sizes varied, the metal contents have been normalized to the contents in a $6 \mathrm{~cm}$ blue mussel (see Data analyses section in text).

Figure 8. $\mathrm{Pb}$ and $\mathrm{Zn}$ contents in blue mussels transplanted from Site L in 2008 and collected at five sites near Maarmorilik in 2009. The distances from the former waste rock dump area are shown in parentheses. The metal contents have been normalized to the contents in a $6 \mathrm{~cm}$ blue mussel (see Data analyses section in text). 
Research highlights for the article: "Long-term response of an arctic fiord system to submarine disposal of mine waste: The environment at Maarmorilik, West Greenland two decades after mine closure."

- A case-study of an arctic fiord systems long-term response to mining pollution.

- Two decades after mine closure the fiord is still contaminated with lead and zinc.

- Metals are still elevated in seaweed and blue mussels twelve $\mathrm{km}$ from the mine.

- Zinc is still released from marine-disposed mine tailings while lead is probably not.

- Transplantation of blue mussels provides a way of monitoring annual contamination. 
Table S-1. Resident and transplanted blue mussels from selected sites in Maarmorilik sampled from 1985 to 2009. Transplanted mussels were collected at an unpolluted reference site (Site L), transplanted in nets, and collected at the sampling sites one year after. When different size groups exist, mussels with a length of 5-6 cm is preferred, thereafter 6-7 cm, and finally $4-5 \mathrm{~cm}$.

\begin{tabular}{|c|c|c|c|c|c|c|c|c|c|c|c|c|c|c|}
\hline Station & $\begin{array}{l}\text { Resident } \\
\text { (Nat) or } \\
\text { transplant } \\
\text { ed (Trans) }\end{array}$ & Year & $\begin{array}{l}\text { Size } \\
\text { group } \\
\text { (cm) }\end{array}$ & $\begin{array}{l}\text { Number of } \\
\text { individuals }\end{array}$ & $\begin{array}{l}\text { Mean } \\
\text { length } \\
(\mathrm{cm})\end{array}$ & $\begin{array}{l}\text { Mean } \\
\text { ind. } \\
\text { wet wt. } \\
\text { (g) }\end{array}$ & $\begin{array}{l}\text { Mean } \\
\text { ind. dry } \\
\text { wt. (g) }\end{array}$ & $\begin{array}{l}\text { Dry } \\
\text { wt. } \\
(\%)\end{array}$ & $\begin{array}{l}\mathrm{Pb}(\mu \mathrm{g} / \mathrm{g} \\
\text { dry wt.) }\end{array}$ & $\begin{array}{l}\text { Zn ( } \mu \mathrm{g} / \mathrm{g} \\
\text { dry wt.) }\end{array}$ & $\begin{array}{l}\mathrm{Pb} p r \\
\text { mussel } \\
(\mu \mathrm{g})\end{array}$ & $\begin{array}{l}\text { Zn pr. } \\
\text { mussel } \\
(\mu \mathrm{g})\end{array}$ & $\begin{array}{l}\mathrm{Pb} \text { in } 6 \mathrm{~cm} \\
\text { mussel } \\
(\mu \mathrm{g})^{*}\end{array}$ & $\begin{array}{l}\mathrm{Zn} \text { in } 6 \mathrm{~cm} \\
\text { musling } \\
(\mu \mathrm{g})^{\star}\end{array}$ \\
\hline T22 & Nat & 2009 & $5-6$ & 16 & 5.5 & 4.6 & 0.8 & 17 & 32 & 129 & 25 & 99 & 32 & 126 \\
\hline T25 & Nat & 2009 & $5-6$ & 20 & 5.5 & 4.5 & 0.7 & 15 & 12 & 109 & 8 & 75 & 10 & 92 \\
\hline Т30 & Nat & 2009 & $5-6$ & 18 & 5.5 & 4.4 & 0.7 & 15 & 15 & 128 & 10 & 86 & 13 & 105 \\
\hline T36 & Nat & 2009 & $5-6$ & 17 & 5.5 & 3.5 & 0.6 & 16 & 20 & 136 & 11 & 75 & 14 & 92 \\
\hline T5 & Trans & 2009 & $5-6$ & 11 & 5.4 & 4.5 & 0.5 & 12 & 15 & 274 & 8 & 143 & 10 & 185 \\
\hline T12SW & Trans & 2009 & $5-6$ & 8 & 5.5 & 5.4 & 0.8 & 14 & 70 & 245 & 53 & 185 & 66 & 230 \\
\hline T17A & Trans & 2009 & $5-6$ & 5 & 5.4 & 5.2 & 0.7 & 14 & 18 & 209 & 13 & 156 & 17 & 201 \\
\hline T22 & Trans & 2009 & $5-6$ & 6 & 5.3 & 4.0 & 0.6 & 14 & 16 & 298 & 9 & 169 & 12 & 229 \\
\hline T36 & Trans & 2009 & $5-6$ & 10 & 5.4 & 3.7 & 0.5 & 13 & 9 & 229 & 4 & 108 & 6 & 140 \\
\hline T22 & Trans & 2008 & $5-7$ & 14 & 6.0 & 5.3 & 0.6 & 12 & 14 & 176 & 8 & 108 & 8 & 108 \\
\hline T36 & Trans & 2008 & $5-6$ & 19 & 5.3 & 3.6 & 0.5 & 14 & 7 & 205 & 4 & 103 & 5 & 139 \\
\hline T5 & Nat & 2008 & $5-6$ & 20 & 5.5 & 8.0 & 1.1 & 13 & 42 & 163 & 45 & 176 & 57 & 224 \\
\hline T12SW & Nat & 2008 & $5-6$ & 18 & 5.6 & 4.5 & 0.6 & 14 & 227 & 474 & 144 & 301 & 174 & 363 \\
\hline T17A & Nat & 2008 & $5-6$ & 20 & 5.4 & 4.3 & 0.6 & 14 & 37 & 117 & 22 & 70 & 29 & 91 \\
\hline T25 & Nat & 2008 & $5-6$ & 20 & 5.5 & 4.2 & 0.6 & 14 & 18 & 123 & 10 & 70 & 13 & 88 \\
\hline T30 & Nat & 2008 & $5-6$ & 20 & 5.5 & 3.7 & 0.5 & 14 & 29 & 112 & 16 & 60 & 20 & 77 \\
\hline T36 & Nat & 2008 & $5-6$ & 20 & 5.7 & 3.9 & 0.3 & 9 & 20 & 123 & 7 & 41 & 8 & 47 \\
\hline T5 & Nat & 2007 & $5-6$ & 20 & 5.5 & 6.0 & 1.0 & 16 & 21 & 120 & 20 & 116 & 25 & 145 \\
\hline T12SW & Nat & 2007 & $5-6$ & 20 & 5.5 & 5.2 & 0.6 & 12 & 155 & 386 & 98 & 245 & 120 & 300 \\
\hline T17A & Nat & 2007 & $5-6$ & 20 & 5.5 & 4.0 & 0.6 & 16 & 31 & 135 & 19 & 84 & 24 & 105 \\
\hline T22 & Nat & 2007 & $5-6$ & 20 & 5.5 & 3.2 & 0.5 & 16 & 34 & 171 & 17 & 88 & 21 & 109 \\
\hline T25 & Nat & 2007 & $5-6$ & 20 & 5.5 & 5.9 & 0.9 & 15 & 21 & 212 & 18 & 184 & 23 & 231 \\
\hline T30 & Nat & 2007 & $5-6$ & 20 & 5.5 & 3.6 & 0.4 & 12 & 26 & 174 & 12 & 78 & 14 & 97 \\
\hline T36 & Nat & 2007 & $5-6$ & 20 & 5.5 & 3.8 & 0.4 & 12 & 16 & 150 & 7 & 66 & 9 & 83 \\
\hline T5 & Nat & 2005 & $5-6$ & 20 & 5.5 & 5.7 & 1.2 & 21 & 13 & 102 & 15 & 119 & 19 & 149 \\
\hline T12SW & Nat & 2005 & $5-6$ & 20 & 5.6 & 5.5 & 1.0 & 18 & 139 & 272 & 138 & 271 & 168 & 328 \\
\hline T17A & Nat & 2005 & $5-6$ & 20 & 5.5 & 3.9 & 0.6 & 15 & 26 & 133 & 15 & 76 & 19 & 95 \\
\hline T22 & Nat & 2005 & $5-6$ & 20 & 5.5 & 4.4 & 0.7 & 17 & 24 & 130 & 17 & 95 & 21 & 117 \\
\hline T25 & Nat & 2005 & $5-6$ & 20 & 5.5 & 4.7 & 0.7 & 16 & 12 & 140 & 9 & 103 & 11 & 128 \\
\hline Т30 & Nat & 2005 & $5-6$ & 20 & 5.6 & 4.3 & 0.6 & 15 & 17 & 126 & 11 & 79 & 13 & 95 \\
\hline T36 & Nat & 2005 & $5-6$ & 20 & 5.5 & 4.4 & 0.7 & 15 & 14 & 163 & 9 & 107 & 12 & 135 \\
\hline T5 & Trans & 2002 & $5-6$ & 36 & 5.8 & 5.0 & 0.6 & 11 & 26 & 282 & 15 & 162 & 16 & 176 \\
\hline T17A & Trans & 2002 & $5-6$ & 20 & 5.6 & 4.3 & 0.3 & 7 & 33 & 442 & 11 & 141 & 13 & 169 \\
\hline T22 & Trans & 2002 & $4-6$ & 5 & 4.9 & 3.2 & 0.4 & 11 & 66 & 393 & 23 & 139 & 39 & 234 \\
\hline T25 & Trans & 2002 & $5-7$ & 20 & 6.0 & 6.5 & 0.7 & 11 & 12 & 220 & 8 & 151 & 9 & 153 \\
\hline T36 & Trans & 2002 & $5-7$ & 19 & 6.1 & 5.3 & 0.6 & 11 & 10 & 267 & 6 & 155 & 6 & 149 \\
\hline T5 & Nat & 2002 & $5-6$ & 20 & 5.5 & 5.2 & 0.9 & 16 & 29 & 163 & 24 & 139 & 30 & 173 \\
\hline T12SW & Nat & 2002 & $5-6$ & 20 & 5.5 & 4.6 & 0.7 & 15 & 113 & 350 & 80 & 248 & 100 & 311 \\
\hline T17A & Nat & 2002 & $5-6$ & 20 & 5.4 & 4.2 & 0.7 & 16 & 40 & 187 & 27 & 125 & 36 & 167 \\
\hline T22 & Nat & 2002 & $5-6$ & 20 & 5.5 & 4.8 & 0.8 & 16 & 37 & 197 & 28 & 149 & 34 & 185 \\
\hline T25 & Nat & 2002 & $5-6$ & 20 & 5.5 & 4.7 & 0.7 & 15 & 20 & 201 & 15 & 146 & 19 & 184 \\
\hline T30 & Nat & 2002 & $5-6$ & 20 & 5.5 & 4.6 & 0.6 & 13 & 30 & 225 & 18 & 137 & 23 & 171 \\
\hline T36 & Nat & 2002 & $5-6$ & 20 & 5.5 & 4.6 & 0.7 & 14 & 15 & 151 & 10 & 98 & 12 & 123 \\
\hline T5 & Nat & 2000 & $4-5$ & 20 & 4.5 & 2.4 & 0.3 & 13 & 127 & 458 & 40 & 145 & 85 & 306 \\
\hline T12SW & Nat & 2000 & $4-5$ & 20 & 4.6 & 2.8 & 0.4 & 15 & 191 & 584 & 79 & 242 & 159 & 486 \\
\hline T17A & Nat & 2000 & $4-5$ & 20 & 4.5 & 2.5 & 0.4 & 15 & 55 & 224 & 21 & 85 & 42 & 173 \\
\hline Т22 & Nat & 2000 & $4-5$ & 20 & 4.5 & 2.3 & 0.3 & 14 & 51 & 229 & 16 & 75 & 34 & 156 \\
\hline
\end{tabular}




\begin{tabular}{|c|c|c|c|c|c|c|c|c|c|c|c|c|c|c|}
\hline T25 & Nat & 2000 & $4-5$ & 20 & 4.6 & 2.4 & 0.3 & 14 & 29 & 224 & 9 & 72 & 19 & 145 \\
\hline T30 & Nat & 2000 & $4-5$ & 20 & 4.6 & 2.3 & 0.3 & 13 & 48 & 233 & 15 & 73 & 30 & 147 \\
\hline T36 & Nat & 2000 & $4-5$ & 20 & 4.5 & 2.5 & 0.4 & 16 & 18 & 165 & 7 & 65 & 14 & 132 \\
\hline T5 & Trans & 1999 & $4-6$ & 17 & 5.0 & 3.8 & 0.5 & 14 & 16 & 222 & 8 & 113 & 13 & 180 \\
\hline T12SW & Trans & 1999 & $4-6$ & 16 & 5.1 & 3.5 & 0.4 & 11 & 202 & 458 & 79 & 179 & 122 & 277 \\
\hline T17A & Trans & 1999 & $5-7$ & 20 & 5.0 & 2.7 & 0.3 & 13 & 29 & 249 & 10 & 84 & 16 & 134 \\
\hline T22 & Trans & 1999 & $5-6$ & 21 & 5.3 & 4.0 & 0.5 & 12 & 17 & 235 & 8 & 109 & 11 & 147 \\
\hline T25 & Trans & 1999 & $5-6$ & 22 & 5.8 & 4.7 & 0.5 & 11 & 11 & 207 & 6 & 106 & 6 & 115 \\
\hline T30 & Trans & 1999 & $5-6$ & 28 & 5.4 & 4.3 & 0.5 & 12 & 12 & 214 & 7 & 114 & 9 & 149 \\
\hline T36 & Trans & 1999 & $5-7$ & 13 & 5.9 & 5.3 & 0.6 & 11 & 12 & 242 & 7 & 145 & 7 & 149 \\
\hline T5 & Nat & 1998 & - & 30 & 3.9 & 2.3 & 0.4 & 17 & 23 & 114 & 9 & 45 & 27 & 137 \\
\hline T12SW & Nat & 1998 & - & 15 & 8.2 & 11.7 & 1.4 & 12 & 1173 & 598 & 1681 & 857 & 765 & 390 \\
\hline T17A & Nat & 1998 & - & 17 & 7.0 & 8.6 & 1.0 & 11 & 224 & 248 & 220 & 243 & 147 & 163 \\
\hline T22 & Nat & 1998 & - & 30 & 3.3 & 1.1 & 0.2 & 16 & 38 & 180 & 6 & 30 & 29 & 139 \\
\hline T25 & Nat & 1998 & - & 17 & 7.9 & 9.8 & 1.1 & 11 & 169 & 319 & 186 & 352 & 92 & 174 \\
\hline T30 & Nat & 1998 & - & 15 & 8.1 & 10.7 & 1.1 & 11 & 252 & 281 & 284 & 317 & 135 & 150 \\
\hline T36 & Nat & 1998 & - & 18 & 7.1 & 8.5 & 0.9 & 10 & 117 & 216 & 104 & 193 & 67 & 124 \\
\hline T5 & Trans & 1997 & - & 16 & 5.4 & 6.0 & 0.7 & 12 & 23 & 201 & 17 & 148 & 22 & 194 \\
\hline T12SW & Trans & 1997 & - & 18 & 4.8 & 3.8 & 0.4 & 11 & 154 & 471 & 63 & 194 & 111 & 340 \\
\hline T17A & Trans & 1997 & - & 16 & 5.4 & 5.1 & 0.6 & 12 & 26 & 226 & 16 & 142 & 21 & 188 \\
\hline T22 & Trans & 1997 & - & 19 & 5.6 & 4.7 & 0.7 & 14 & 18 & 221 & 12 & 151 & 14 & 179 \\
\hline T25 & Trans & 1997 & - & 11 & 5.5 & 5.9 & 0.7 & 11 & 9 & 181 & 6 & 118 & 8 & 146 \\
\hline T30 & Trans & 1997 & - & 20 & 5.3 & 3.6 & 0.4 & 11 & 11 & 200 & 5 & 82 & 6 & 114 \\
\hline T36 & Trans & 1997 & - & 20 & 5.7 & 5.9 & 0.6 & 10 & 7 & 218 & 4 & 128 & 5 & 149 \\
\hline T5 & Nat & 1996 & - & 20 & 7.8 & 11.7 & 2.1 & 18 & 329 & 329 & 684 & 684 & 351 & 351 \\
\hline T12SW & Nat & 1996 & - & 20 & 7.1 & 8.3 & 1.3 & 16 & 1126 & 526 & 1486 & 694 & 969 & 453 \\
\hline T17A & Nat & 1996 & - & 19 & 6.8 & 8.3 & 1.3 & 15 & 152 & 279 & 195 & 357 & 142 & 260 \\
\hline T22 & Nat & 1996 & - & 19 & 7.9 & 12.7 & 1.9 & 15 & 304 & 322 & 578 & 612 & 287 & 304 \\
\hline T25 & Nat & 1996 & - & 20 & 7.7 & 9.9 & 1.6 & 16 & 178 & 253 & 287 & 407 & 152 & 216 \\
\hline T30 & Nat & 1996 & - & 20 & 7.3 & 7.7 & 1.1 & 15 & 341 & 352 & 382 & 394 & 232 & 240 \\
\hline T36 & Nat & 1996 & - & 19 & 6.8 & 7.9 & 1.1 & 13 & 69 & 226 & 73 & 240 & 53 & 174 \\
\hline T5 & Trans & 1996 & - & 20 & 4.9 & 3.7 & 0.6 & 16 & 33 & 202 & 20 & 121 & 33 & 203 \\
\hline T12SW & Trans & 1996 & - & 21 & 5.1 & 3.4 & 0.5 & 14 & 272 & 563 & 131 & 270 & 197 & 408 \\
\hline T17A & Trans & 1996 & - & 18 & 4.9 & 2.6 & 0.3 & 13 & 37 & 283 & 12 & 93 & 20 & 156 \\
\hline T22 & Trans & 1996 & - & 18 & 5.9 & 3.2 & 0.5 & 15 & 39 & 264 & 18 & 124 & 19 & 129 \\
\hline T25 & Trans & 1996 & - & 11 & 5.6 & 4.8 & 0.7 & 15 & 15 & 217 & 11 & 154 & 13 & 184 \\
\hline T30 & Trans & 1996 & - & 10 & 5.1 & 3.1 & 0.4 & 12 & 25 & 273 & 9 & 98 & 13 & 149 \\
\hline T36 & Trans & 1996 & - & 18 & 4.8 & 2.4 & 0.3 & 13 & 11 & 227 & 3 & 68 & 6 & 120 \\
\hline T5 & Nat & 1995 & - & 11 & 7.6 & 16.9 & 3.8 & 23 & 194 & 224 & 739 & 853 & 405 & 468 \\
\hline T12SW & Nat & 1995 & - & 20 & 7.8 & 17.4 & 3.4 & 20 & 655 & 290 & 2247 & 995 & 1154 & 511 \\
\hline T17A & Nat & 1995 & - & 20 & 6.9 & 10.6 & 2.2 & 20 & 166 & 231 & 357 & 497 & 250 & 348 \\
\hline T22 & Nat & 1995 & - & 17 & 7.5 & 15.0 & 3.5 & 23 & 180 & 208 & 632 & 730 & 358 & 414 \\
\hline T25 & Nat & 1995 & - & 20 & 7.3 & 13.0 & 2.6 & 20 & 116 & 205 & 300 & 531 & 183 & 323 \\
\hline T30 & Nat & 1995 & - & 20 & 7.3 & 10.9 & 2.0 & 18 & 114 & 187 & 223 & 367 & 136 & 223 \\
\hline T36 & Nat & 1995 & - & 18 & 7.8 & 14.5 & 3.2 & 22 & 72 & 139 & 230 & 446 & 118 & 229 \\
\hline T5 & Trans & 1995 & - & 5 & 6.5 & 13.1 & 2.9 & 22 & 10 & 87 & 29 & 255 & 24 & 208 \\
\hline T12SW & Trans & 1995 & - & 7 & 6.6 & 10.4 & 2.0 & 20 & 82 & 213 & 168 & 435 & 132 & 341 \\
\hline T17A & Trans & 1995 & - & 7 & 6.6 & 7.7 & 1.2 & 16 & 15 & 157 & 18 & 193 & 14 & 152 \\
\hline T22 & Trans & 1995 & - & 7 & 6.7 & 10.7 & 2.1 & 20 & 11 & 99 & 23 & 206 & 18 & 156 \\
\hline T25 & Trans & 1995 & - & 6 & 6.7 & 12.2 & 2.4 & 20 & 5 & 109 & 11 & 262 & 9 & 198 \\
\hline T30 & Trans & 1995 & - & 7 & 6.6 & 7.1 & 1.3 & 18 & 8 & 132 & 11 & 168 & 8 & 132 \\
\hline T36 & Trans & 1995 & - & 7 & 6.8 & 11.3 & 2.2 & 19 & 4 & 95 & 8 & 207 & 6 & 151 \\
\hline
\end{tabular}




\begin{tabular}{|c|c|c|c|c|c|c|c|c|c|c|c|c|c|c|}
\hline T5 & Nat & 1994 & $8-9$ & - & 8.5 & 16.6 & 2.3 & 14 & 566 & 436 & 1312 & 1010 & 542 & 417 \\
\hline T12SW & Nat & 1994 & $7-8$ & - & 7.5 & 11.5 & 1.7 & 15 & 984 & 469 & 1659 & 791 & 942 & 449 \\
\hline T17A & Nat & 1994 & $7-8$ & - & 7.5 & 12.9 & 1.7 & 13 & 480 & 529 & 810 & 892 & 459 & 506 \\
\hline T22 & Nat & 1994 & $7-8$ & - & 7.5 & 9.9 & 1.7 & 17 & 390 & 432 & 658 & 729 & 373 & 413 \\
\hline T25 & Nat & 1994 & $7-8$ & - & 7.5 & 11.2 & 1.7 & 15 & 252 & 374 & 425 & 631 & 241 & 358 \\
\hline T30 & Nat & 1994 & $7-8$ & - & 7.5 & 13.1 & 1.7 & 13 & 292 & 212 & 492 & 358 & 279 & 203 \\
\hline T36 & Nat & 1994 & $7-8$ & - & 7.5 & 11.8 & 1.7 & 14 & 159 & 311 & 268 & 524 & 152 & 298 \\
\hline T5 & Trans & 1994 & $7.5-7.9$ & - & 7.7 & 12.0 & 1.8 & 15 & 28 & 130 & 51 & 234 & 27 & 124 \\
\hline T17A & Trans & 1994 & $7.0-7.4$ & - & 7.2 & 13.2 & 1.5 & 12 & 18 & 176 & 28 & 268 & 17 & 168 \\
\hline T22 & Trans & 1994 & $6-7$ & - & 6.5 & 8.5 & 1.2 & 14 & 26 & 170 & 30 & 199 & 25 & 163 \\
\hline T25 & Trans & 1994 & $6-7$ & - & 6.5 & 9.0 & 1.2 & 13 & 14 & 183 & 16 & 215 & 13 & 175 \\
\hline T30 & Trans & 1994 & $6-7$ & - & 6.5 & 10.7 & 1.2 & 11 & 19 & 164 & 22 & 192 & 18 & 157 \\
\hline T36 & Trans & 1994 & $6-7$ & - & 6.5 & 6.6 & 1.2 & 18 & 7 & 131 & 8 & 154 & 7 & 125 \\
\hline T5 & Nat & 1993 & $7-8$ & 20 & 7.5 & 12.8 & 2.1 & 16 & 594 & 378 & 1253 & 798 & 711 & 452 \\
\hline T12SW & Nat & 1993 & $6-7$ & 18 & 6.5 & 9.9 & 1.2 & 13 & 1155 & 472 & 1427 & 583 & 1164 & 476 \\
\hline T17A & Nat & 1993 & $6-7$ & 20 & 6.5 & 6.8 & 0.9 & 14 & 425 & 346 & 397 & 323 & 324 & 264 \\
\hline Т22 & Nat & 1993 & $8-9$ & 18 & 8.5 & 15.5 & 2.2 & 14 & 369 & 324 & 804 & 706 & 332 & 291 \\
\hline T25 & Nat & 1993 & $6-7$ & 19 & 6.5 & 8.2 & 0.9 & 12 & 313 & 347 & 297 & 330 & 243 & 269 \\
\hline T30 & Nat & 1993 & $6-7$ & 20 & 6.5 & 7.3 & 1.0 & 14 & 261 & 337 & 266 & 344 & 217 & 280 \\
\hline T36 & Nat & 1993 & $5-6$ & 15 & 5.5 & 5.7 & 0.8 & 14 & 109 & 350 & 87 & 280 & 109 & 349 \\
\hline T5 & Trans & 1993 & $7.2-7.4$ & 3 & 7.2 & 12.9 & 1.9 & 15 & 18 & 165 & 35 & 317 & 22 & 199 \\
\hline T17A & Trans & 1993 & $7.2-7.4$ & 7 & 7.2 & 11.1 & 1.5 & 14 & 18 & 176 & 27 & 268 & 17 & 168 \\
\hline T22 & Trans & 1993 & $7.2-7.4$ & 7 & 7.2 & 9.7 & 1.2 & 12 & 18 & 205 & 22 & 240 & 14 & 151 \\
\hline T25 & Trans & 1993 & $7.2-7.4$ & 7 & 7.2 & 12.4 & 1.7 & 14 & 14 & 120 & 25 & 208 & 16 & 131 \\
\hline T30 & Trans & 1993 & $7.2-7.4$ & 7 & 7.2 & 10.4 & 1.1 & 11 & 17 & 251 & 18 & 275 & 12 & 173 \\
\hline T36 & Trans & 1993 & $7.2-7.4$ & 7 & 7.2 & 10.2 & 1.2 & 11 & 13 & 203 & 15 & 236 & 9 & 149 \\
\hline T5 & Nat & 1992 & $7-8$ & - & 7.5 & 11.9 & 1.7 & 14 & 733 & 426 & 1236 & 718 & 701 & 408 \\
\hline T12SW & Nat & 1992 & $6-7$ & - & 6.5 & 8.3 & 1.2 & 14 & 1124 & 467 & 1318 & 548 & 1075 & 447 \\
\hline T17A & Nat & 1992 & $5-6$ & - & 5.5 & 5.6 & 0.8 & 14 & 301 & 349 & 231 & 268 & 288 & 334 \\
\hline T22 & Nat & 1992 & $7-8$ & - & 7.5 & 10.6 & 1.7 & 16 & 441 & 445 & 744 & 750 & 422 & 426 \\
\hline T25 & Nat & 1992 & $6-7$ & - & 6.5 & 7.2 & 1.2 & 16 & 237 & 429 & 278 & 503 & 227 & 410 \\
\hline T30 & Nat & 1992 & $6-7$ & - & 6.5 & 8.2 & 1.2 & 14 & 198 & 353 & 232 & 414 & 189 & 338 \\
\hline T36 & Nat & 1992 & $5-6$ & - & 5.5 & 4.8 & 0.8 & 16 & 139 & 229 & 107 & 176 & 133 & 219 \\
\hline T17A & Trans & 1992 & $7.0-7.4$ & - & 7.2 & 11.1 & 1.5 & 14 & 28 & 180 & 42 & 274 & 26 & 172 \\
\hline T22 & Trans & 1992 & $7.0-7.4$ & - & 7.2 & 13.2 & 1.5 & 11 & 28 & 262 & 43 & 398 & 27 & 251 \\
\hline T25 & Trans & 1992 & $7.0-7.4$ & - & 7.2 & 10.9 & 1.5 & 14 & 13 & 171 & 20 & 260 & 12 & 164 \\
\hline T30 & Trans & 1992 & $7.5-7.9$ & - & 7.7 & 14.7 & 1.8 & 12 & 19 & 210 & 35 & 379 & 18 & 201 \\
\hline T36 & Trans & 1992 & $7.0-7.4$ & - & 7.2 & 11.7 & 1.5 & 13 & 15 & 190 & 23 & 289 & 14 & 182 \\
\hline T5 & Nat & 1991 & $7-8$ & 19 & 7.5 & 12.7 & 2.0 & 15 & 718 & 382 & 1404 & 747 & 796 & 424 \\
\hline T12SW & Nat & 1991 & $6-7$ & 20 & 6.5 & 8.4 & 1.3 & 16 & 972 & 404 & 1295 & 538 & 1057 & 439 \\
\hline T17A & Nat & 1991 & $5-6$ & 20 & 5.5 & 4.1 & 0.6 & 14 & 310 & 317 & 182 & 186 & 227 & 232 \\
\hline T22 & Nat & 1991 & 6-7 & 17 & 6.5 & 8.0 & 1.3 & 16 & 406 & 373 & 525 & 483 & 429 & 394 \\
\hline T25 & Nat & 1991 & $6-7$ & 19 & 6.5 & 7.1 & 1.2 & 16 & 276 & 375 & 322 & 438 & 263 & 357 \\
\hline T30 & Nat & 1991 & $6-7$ & 19 & 6.5 & 6.4 & 1.1 & 17 & 335 & 465 & 363 & 504 & 296 & 411 \\
\hline T36 & Nat & 1991 & $5-6$ & 20 & 5.5 & 4.8 & 1.0 & 20 & 176 & 319 & 169 & 306 & 210 & 381 \\
\hline T5 & Nat & 1990 & $6-7$ & - & 6.5 & 7.4 & 1.2 & 16 & 845 & 603 & 991 & 707 & 809 & 577 \\
\hline T12SW & Nat & 1990 & $6-7$ & - & 6.5 & 8.1 & 1.2 & 15 & 2031 & 1012 & 2381 & 1187 & 1943 & 968 \\
\hline T17A & Nat & 1990 & $6-7$ & - & 6.5 & 8.5 & 1.2 & 14 & 509 & 637 & 597 & 747 & 487 & 609 \\
\hline T22 & Nat & 1990 & $7-8$ & - & 7.5 & 10.9 & 1.7 & 15 & 567 & 576 & 956 & 971 & 543 & 551 \\
\hline T25 & Nat & 1990 & $6-7$ & - & 6.5 & 8.2 & 1.2 & 14 & 332 & 553 & 389 & 648 & 318 & 529 \\
\hline Т30 & Nat & 1990 & $6-7$ & - & 6.5 & 8.1 & 1.2 & 14 & 460 & 503 & 539 & 590 & 440 & 481 \\
\hline T36 & Nat & 1990 & $5-6$ & - & 5.5 & 5.9 & 0.8 & 13 & 233 & 428 & 179 & 328 & 223 & 410 \\
\hline
\end{tabular}




\begin{tabular}{|c|c|c|c|c|c|c|c|c|c|c|c|c|c|c|}
\hline T5 & Nat & 1989 & $6-7$ & - & 6.5 & 7.7 & 1.2 & 15 & 658 & 430 & 772 & 504 & 630 & 411 \\
\hline T12SW & Nat & 1989 & $7-9$ & - & 8.0 & 14.3 & 2.0 & 14 & 2647 & 676 & 5259 & 1343 & 2533 & 647 \\
\hline T17A & Nat & 1989 & $5-6$ & - & 5.5 & 5.4 & 0.8 & 14 & 334 & 322 & 256 & 247 & 320 & 308 \\
\hline T22 & Nat & 1989 & $6-7$ & - & 6.5 & 7.4 & 1.2 & 16 & 628 & 494 & 736 & 579 & 601 & 473 \\
\hline T25 & Nat & 1989 & $6-7$ & - & 6.5 & 8.0 & 1.2 & 15 & 341 & 449 & 400 & 526 & 326 & 430 \\
\hline Т30 & Nat & 1989 & $6-7$ & - & 6.5 & 8.6 & 1.2 & 14 & 322 & 407 & 378 & 477 & 308 & 389 \\
\hline Т36 & Nat & 1989 & $5-6$ & - & 5.5 & 4.7 & 0.8 & 16 & 115 & 240 & 88 & 184 & 110 & 230 \\
\hline T5 & Nat & 1988 & $6-7$ & - & 6.5 & 8.0 & 1.2 & 15 & 566 & 405 & 664 & 475 & 542 & 388 \\
\hline T12SW & Nat & 1988 & $6-7$ & - & 6.5 & 7.4 & 1.2 & 16 & 1536 & 558 & 1801 & 654 & 1470 & 534 \\
\hline T17A & Nat & 1988 & $5-6$ & - & 5.5 & 4.9 & 0.8 & 16 & 330 & 392 & 253 & 301 & 316 & 375 \\
\hline T22 & Nat & 1988 & $6-7$ & - & 6.5 & 6.9 & 1.2 & 17 & 498 & 489 & 584 & 573 & 476 & 468 \\
\hline T25 & Nat & 1988 & $6-7$ & - & 6.5 & 6.8 & 1.2 & 17 & 264 & 433 & 310 & 508 & 253 & 414 \\
\hline Т30 & Nat & 1988 & $5-6$ & - & 5.5 & 5.4 & 0.8 & 14 & 314 & 436 & 241 & 334 & 300 & 417 \\
\hline T36 & Nat & 1988 & $5-6$ & - & 5.5 & 4.8 & 0.8 & 16 & 168 & 371 & 129 & 285 & 161 & 355 \\
\hline T17A & Nat & 1987 & $5-6$ & 17 & 5.5 & 4.8 & 0.8 & 16 & 292 & 282 & 222 & 214 & 276 & 266 \\
\hline T17A & Nat & 1986 & $5-6$ & 19 & 5.4 & 4.9 & 0.6 & 12 & 239 & 276 & 143 & 166 & 188 & 217 \\
\hline T17A & Nat & 1985 & $5-6$ & 12 & 5.3 & 4.9 & 0.8 & 17 & 285 & 354 & 231 & 287 & 316 & 393 \\
\hline T17A & Trans & 1985 & - & 5 & 7.2 & 10.3 & 1.3 & 12 & 131 & 193 & 168 & 247 & 107 & 158 \\
\hline
\end{tabular}


Table S-2. Metal concentrations in sediment, in $\mathrm{mg} \mathrm{kg}^{-1}$, measured in a sediment profile taken at Station 12 in Qaamarujuk in 2005.

\begin{tabular}{ccccccc}
\hline Depth $(\mathrm{cm})$ & $\mathrm{Zn}$ & $\mathrm{Pb}$ & $\mathrm{Cd}$ & $\mathrm{Hg}$ & $\mathrm{As}$ & $\mathrm{Al}$ \\
\hline 0.5 & 236 & 173 & 0.18 & 0.021 & 19 & 39616 \\
1.5 & 262 & 186 & 0.30 & 0.023 & 21 & 40799 \\
2.5 & 298 & 187 & 0.75 & 0.022 & 18 & 40939 \\
3.5 & 265 & 94 & 0.87 & 0.018 & 13 & 45965 \\
4.5 & 165 & 45 & 0.43 & 0.014 & 11 & 45205 \\
5.5 & 143 & 34 & 0.24 & 0.010 & 10 & 42719 \\
6.5 & 144 & 32 & 0.28 & 0.010 & 10 & 45642 \\
7.5 & 143 & 29 & 0.26 & 0.010 & 10 & 44482 \\
8.5 & 131 & 28 & 0.23 & 0.011 & 10 & 43892 \\
9.5 & 132 & 28 & 0.20 & 0.009 & 10 & 45072 \\
10.5 & 130 & 26 & 0.21 & 0.010 & 10 & 45592 \\
11.5 & 125 & 25 & 0.21 & 0.007 & 10 & 43737 \\
12.5 & 126 & 26 & 0.21 & 0.009 & 10 & 45407 \\
13.5 & 124 & 25 & 0.23 & 0.009 & 10 & 44745 \\
\hline
\end{tabular}




\begin{tabular}{lcccccccccc}
\hline Site & Dissolved & $(<0.45 \mu \mathrm{m})$ & \multicolumn{4}{c}{ Particulate $(>0.45 \mu \mathrm{m})$} & \multicolumn{3}{c}{ Near-shore sediment } \\
& $\begin{array}{c}\mathrm{Pb} \\
\left(\mu \mathrm{g} \mathrm{L}^{-1}\right)\end{array}$ & $\begin{array}{c}\mathrm{Zn} \\
\left(\mu \mathrm{g} \mathrm{L}^{-1}\right)\end{array}$ & $\begin{array}{c}\mathrm{Pb} \\
\left(\mu \mathrm{g} \mathrm{g}^{-1}\right)\end{array}$ & $\begin{array}{c}\mathrm{Zn} \\
\left(\mu \mathrm{g} \mathrm{g}^{-1}\right)\end{array}$ & $\begin{array}{c}\mathrm{Pb} / \mathrm{Al} \\
\left(10^{-4}\right)\end{array}$ & $\begin{array}{c}\mathrm{Zn} / \mathrm{Al} \\
\left(10^{-4}\right)\end{array}$ & $\begin{array}{c}\mathrm{Pb} \\
\left(\mu \mathrm{g} \mathrm{g}^{-1}\right)\end{array}$ & $\begin{array}{c}\mathrm{Zn} \\
\left(\mu \mathrm{g} \mathrm{g}^{-1}\right)\end{array}$ & $\begin{array}{c}\mathrm{Pb} / \mathrm{Al} \\
\left(10^{-4}\right)\end{array}$ & $\begin{array}{c}\mathrm{Zn} / \mathrm{Al} \\
\left(10^{-4}\right)\end{array}$ \\
\hline T12SV & 0.46 & 2.44 & 75 & 11 & 31 & 218 & 213 & 436 & 69 & 139 \\
T22 & 0.07 & 0.47 & 14 & 1 & 21 & 291 & 6 & 42 & 12 & 80 \\
T25 & 0.11 & 0.78 & 34 & 2 & 5 & 96 & 4 & 38 & 2 & 22 \\
T29 & 0.11 & 0.77 & 29 & 1 & 5 & 107 & 8 & 35 & 1 & 6 \\
T30 & 0.12 & 0.52 & 31 & 2 & 5 & 70 & 15 & 55 & 3 & 13 \\
T36 & 0.06 & 0.13 & 26 & 6 & 2 & 7 & 9 & 20 & 2 & 3 \\
T37 & 0.04 & 0.63 & 25 & 1 & 3 & 53 & 7 & 27 & 2 & 5 \\
$\mathrm{~L}$ & $\mathrm{ND}^{\text {a }}$ & $\mathrm{ND}$ & 15 & 3 & 2 & 11 & 14 & 13 & 3 & 2 \\
\hline
\end{tabular}

${ }^{\mathrm{a}} \mathrm{ND}=$ Not determined

Table 1. Søndergaard et al., 2011. 


\begin{tabular}{lcccc}
\hline Element & Seaweed & & \multicolumn{2}{c}{ Blue mussels } \\
& Site L & Site T12SW & $\begin{array}{c}\text { Before } \\
\text { transplantation } \\
\text { (Site L) }\end{array}$ & $\begin{array}{c}\text { After onear } \\
\text { transplantation at } \\
\text { Site T12SV }\end{array}$ \\
\hline $\mathrm{Pb}$ & 0.1 & 3.0 & 3 & 70 \\
$\mathrm{Zn}$ & 8 & 130 & 146 & 245 \\
$\mathrm{As}$ & 43 & 72 & 16 & 17 \\
$\mathrm{Cd}$ & 0.8 & 1.1 & 3.3 & 2.8 \\
$\mathrm{Hg}$ & 0.070 & 0.017 & 0.12 & 0.11 \\
\hline
\end{tabular}

Table 2. Søndergaard et al., 2011. 


\begin{tabular}{|c|c|c|c|c|c|}
\hline Site & Element & $\begin{array}{c}\text { Number of } \\
\text { samples }\end{array}$ & $\begin{array}{l}\text { Log-linear } \\
\text { trend }\end{array}$ & $\begin{array}{l}\text { Non-linear } \\
\text { trend }\end{array}$ & $\begin{array}{c}\text { Annual } \\
\text { change }(\%)\end{array}$ \\
\hline \multicolumn{6}{|c|}{ Seaweed } \\
\hline T12SV & $\mathrm{Pb}$ & 13 & sign & - & -8.1 \\
\hline T12SV & $\mathrm{Zn}$ & 13 & - & - & -2.8 \\
\hline T17A & $\mathrm{Pb}$ & 12 & sign & - & -5.4 \\
\hline T17A & $\mathrm{Zn}$ & 12 & sign & sign & -1.1 \\
\hline T36 & $\mathrm{Pb}$ & 13 & - & - & -1.0 \\
\hline T36 & $\mathrm{Zn}$ & 13 & sign & sign & -3.6 \\
\hline \multicolumn{6}{|c|}{ Blue mussels, resident } \\
\hline T12SV & $\mathrm{Pb}$ & 12 & sign & sign & -15.4 \\
\hline T12SV & $\mathrm{Zn}$ & 12 & sign & & -2.4 \\
\hline T17A & $\mathrm{Pb}$ & 12 & sign & & -18.2 \\
\hline T17A & $\mathrm{Zn}$ & 12 & sign & - & -8.1 \\
\hline T36 & $\mathrm{Pb}$ & 13 & sign & - & -18.2 \\
\hline T36 & $\mathrm{Zn}$ & 13 & sign & & -8.6 \\
\hline \multicolumn{6}{|c|}{ Blue mussels, transplanted } \\
\hline T12SV & $\mathrm{Pb}$ & 5 & - & - & -5.9 \\
\hline T12SV & $\mathrm{Zn}$ & 5 & & - & -3.4 \\
\hline T17A & $\mathrm{Pb}$ & 9 & & - & -1.7 \\
\hline T17A & $\mathrm{Zn}$ & 9 & sign & - & +0.8 \\
\hline T36 & $\mathrm{Pb}$ & 9 & sign & sign & -3.4 \\
\hline T36 & $\mathrm{Zn}$ & 9 & - & - & -0.4 \\
\hline
\end{tabular}

Table 3. Søndergaard et al., 2011 


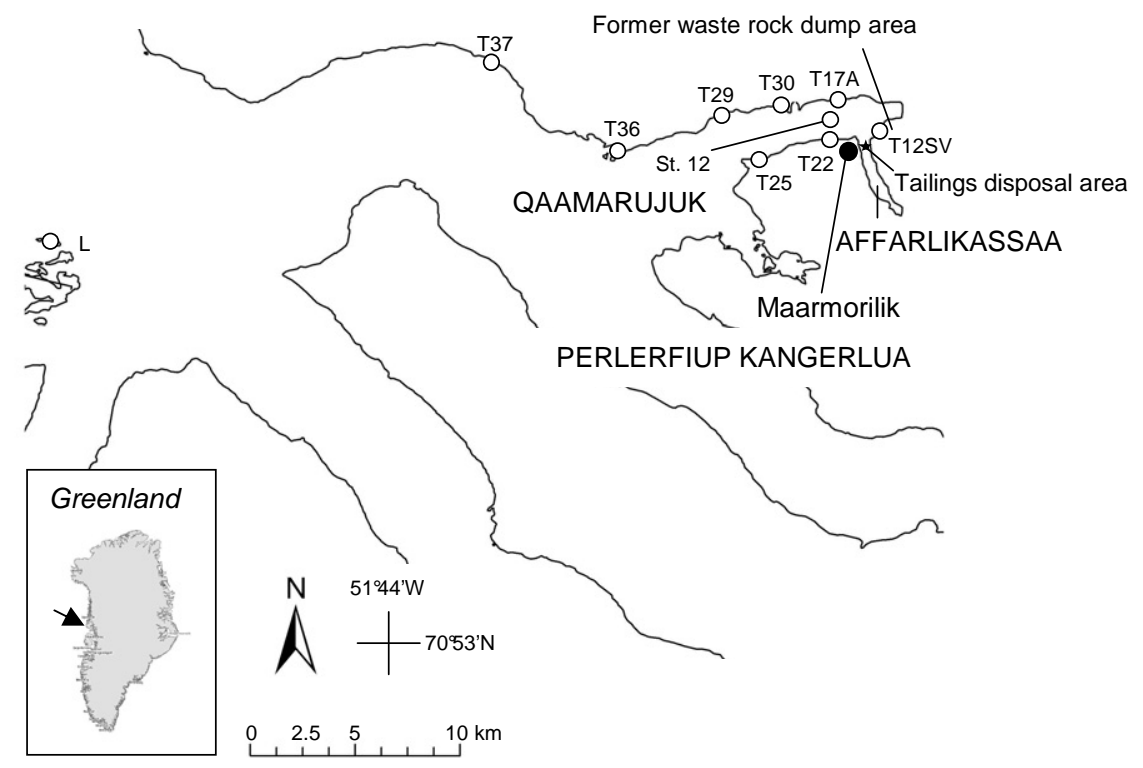

Figure 1. Søndergaard et al., 2011 


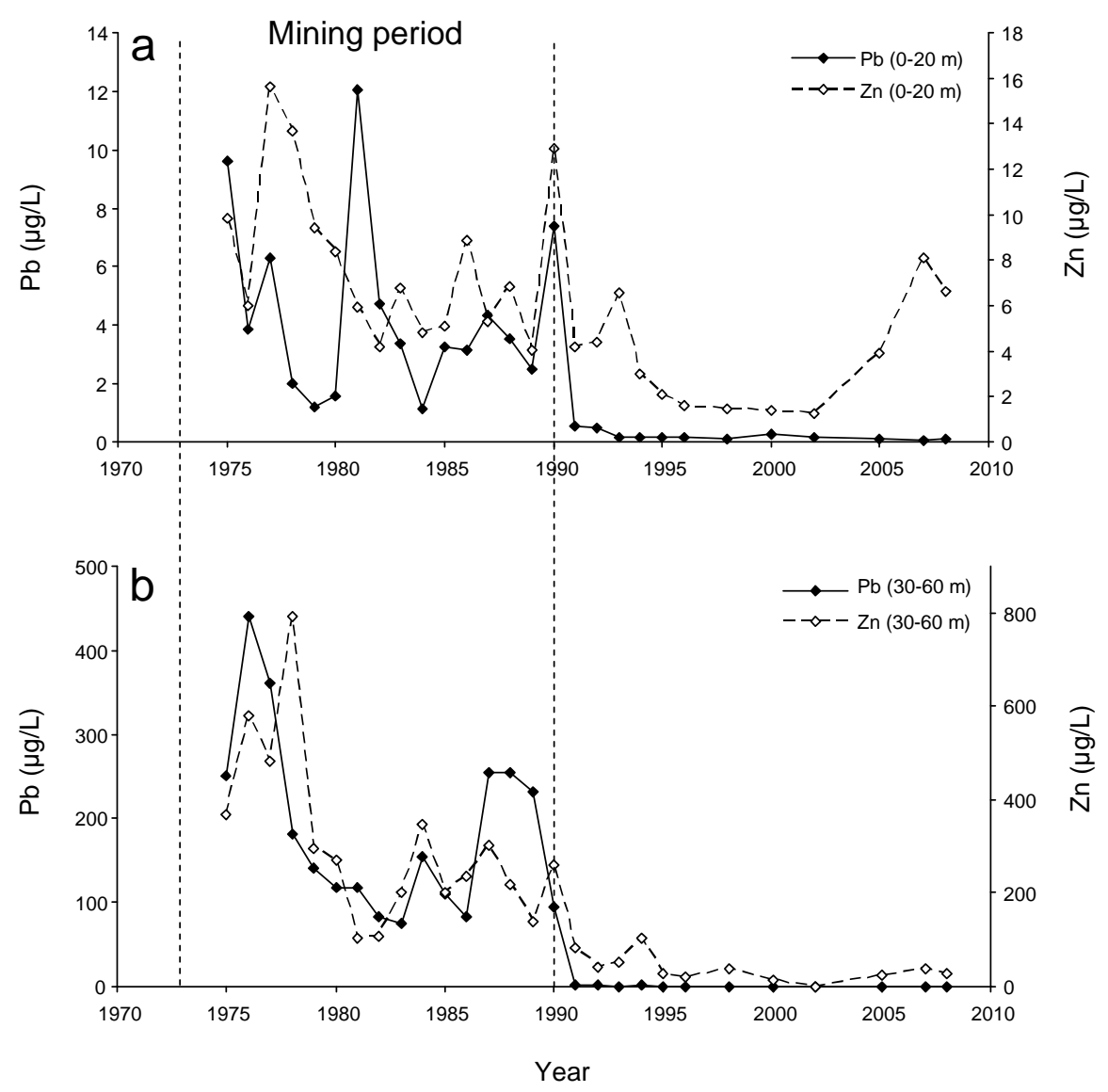

Figure 2. Søndergaard et al., 2011 
Element/Al

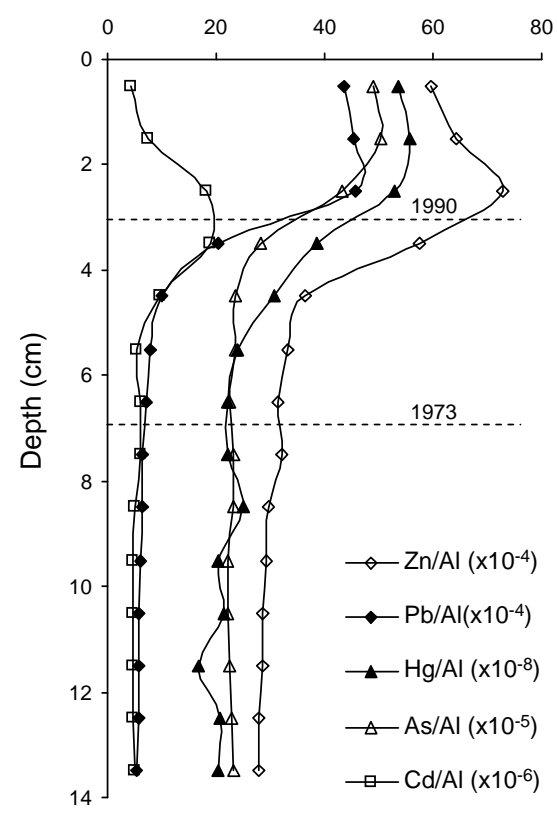

Figure 3. Søndergaard et al., 2011 

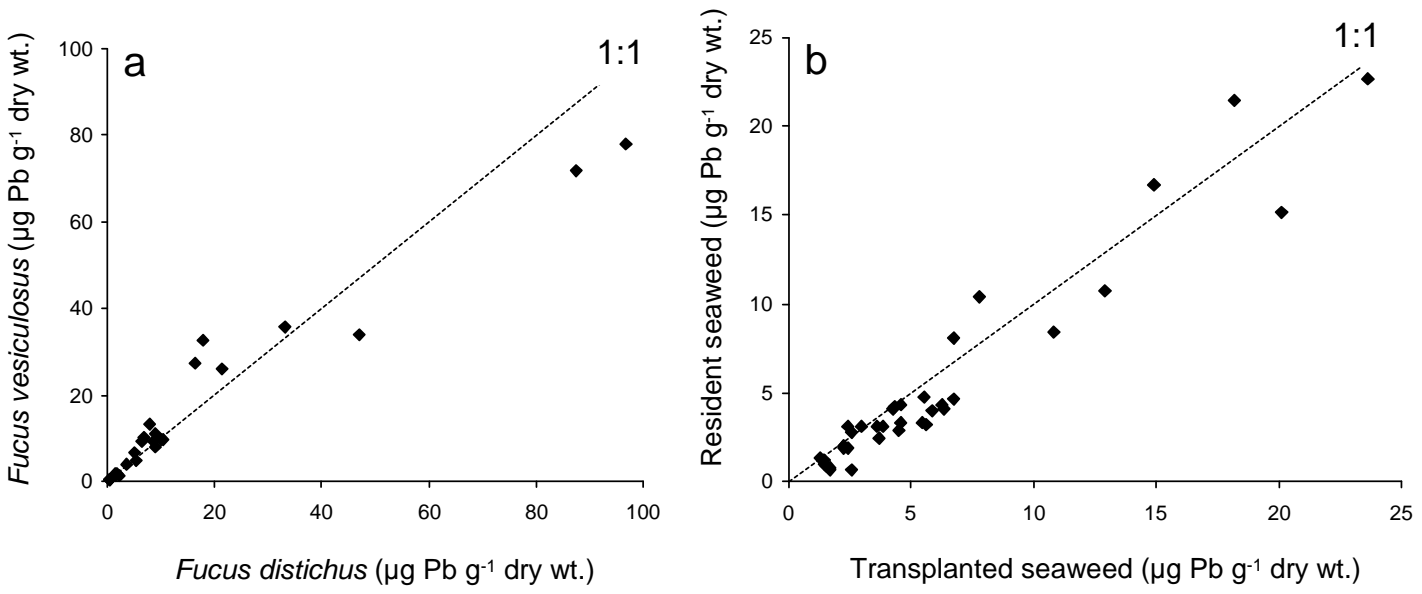

Figure 4. Søndergaard et al., 2011 

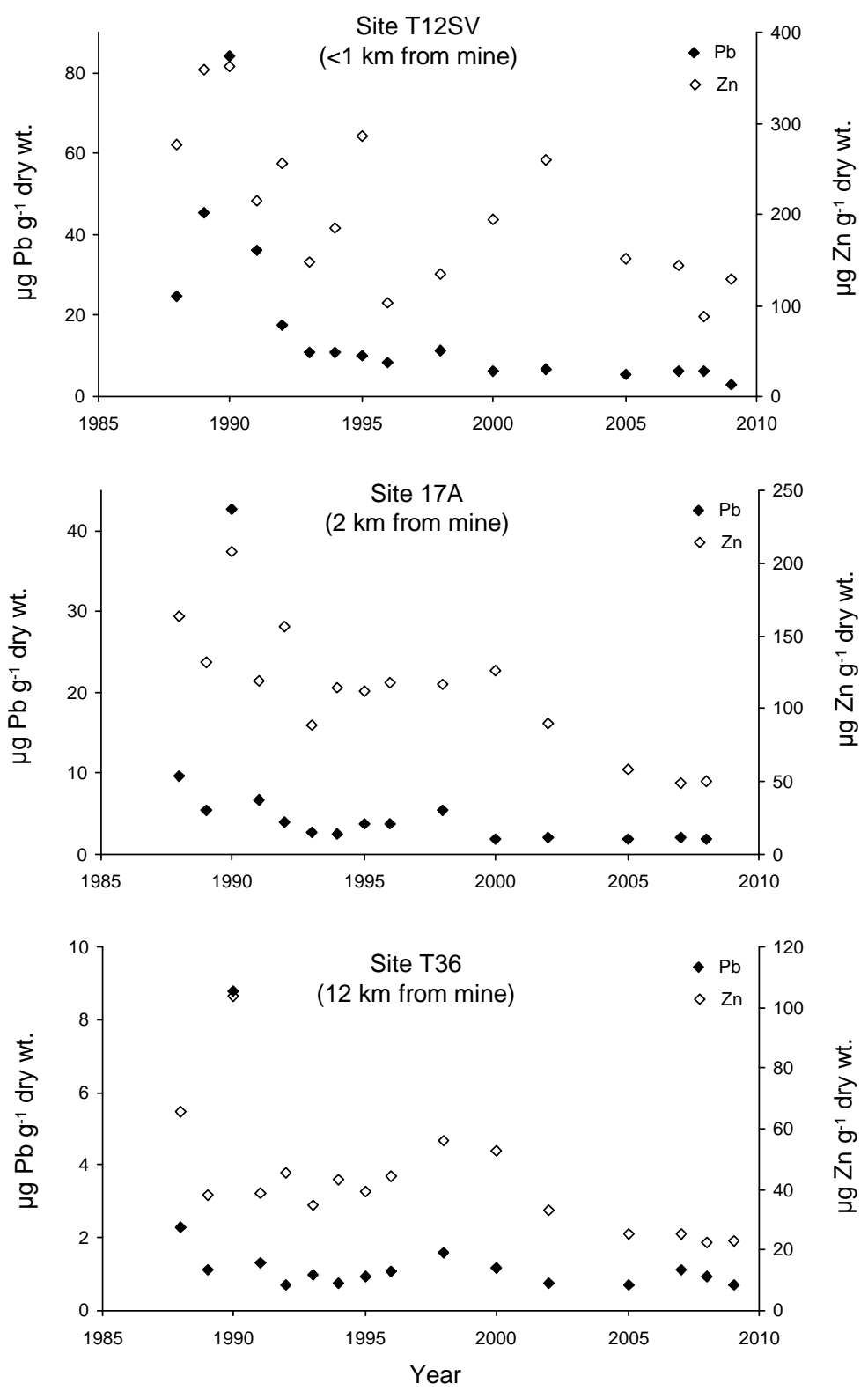

Figure 5. Søndergaard et al., 2011 


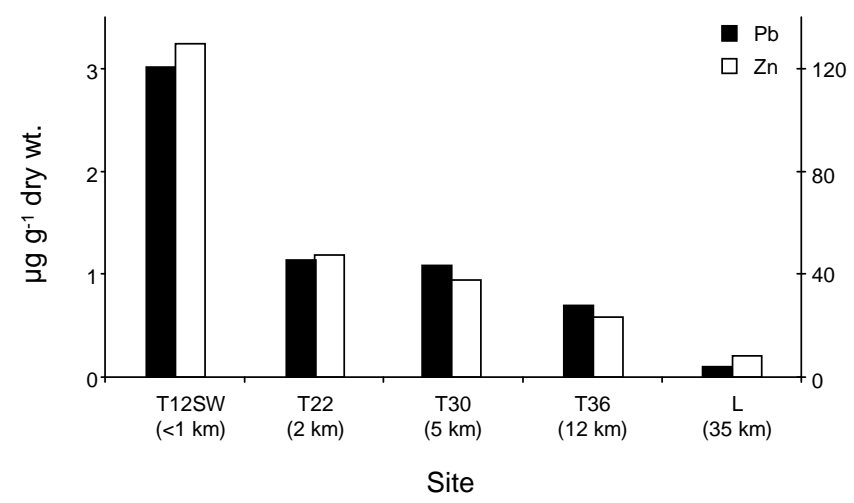

Figure 6. Søndergaard et al., 2011 

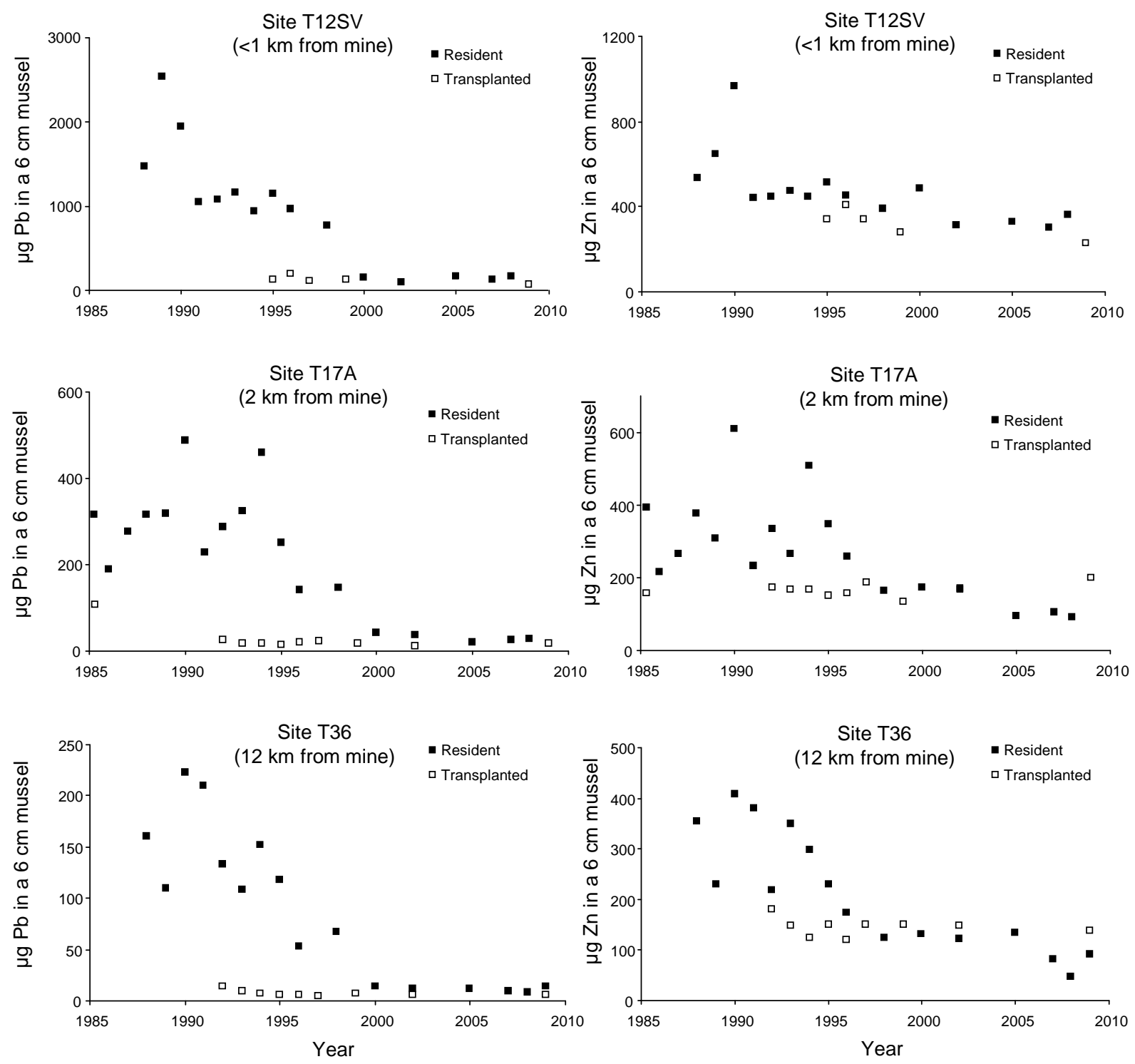

Figure 7. Søndergaard et al., 2011 


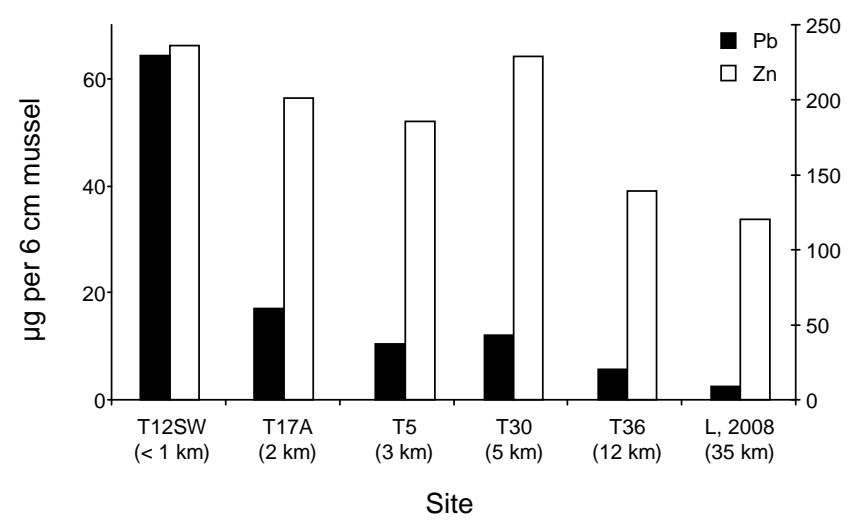

Figure 8. Søndergaard et al., 2011 